\title{
Polyelerde Hatalı Arazi Kullanımların Sebep Olduğu Afetlere Bir Örnek: 31 Ocak 2019 Kayaköy Polyesi Taşkını
}

\author{
An Example for the Disasters Caused by Improper Land Use: The Kayaköy Polje Flood of \\ January 31, 2019
}

Cihan BAYRAKDAR ${ }^{1}$ (D), Mehmet Fatih DÖKER ${ }^{2}$ (D), Ferhat KESERCI $\dot{I}^{3}$ (1)

'İstanbul Üniversitesi, Edebiyat Fakültesi, Coğrafya Bölümü, İstanbul, Türkiye

${ }^{2}$ Sakarya Üniversitesi, Fen Edebiyat Fakültesi, Coğrafya Bölümü, Sakarya, Türkiye

${ }^{3}$ İstanbul Üniversitesi, Sosyal Bilimler Enstitüsü, Coğrafya Anabilim Dalı, İstanbul, Türkiye

ORCID: C.B. 0000-0001-5542-700X; M.F.D. 0000-0002-0414-0428; F.K. 0000-0002-8653-6177

\section{öz}

Kayaköy Polyesi Fethiye'nin 6 km güneyinde deniz seviyesinden 140 m yükseklikte, 5 km uzunluğunda, 2 km eninde ve 5 km² alana sahip dolomitler içinde oluşmuş dış drenaja kapalı tipik bir karstik depresyondur. Kayaköy Polyesi Havzası ise 43 km² alan kaplayıp doğuda yer alan Ovacık-Hisarönü ovalarını da kapsar ve havzanın suları polyenin batısında tespit edilen iki düden ile dış drenaja bağlanır. 31 Ocak 2019 tarihinde Fethiye ve yakın çevresinde aşırı yağışlar sonucu Kayaköy Polyesi'nde oluşan taşkın, yerleşmeler ile tarım alanlarını sular altında bırakmış, taşkının etkisi birkaç ay süre ile devam etmiştir. Bu taşkının afete dönüşmesinde yağış faktörü, karstik süreçler ve arazi kullanım özelliklerinin etkilerini araştııılmış ve çözüm önerileri getirilmiştir. Bu kapsamda arazi çalışmaları, insansız hava aracı, uydu görüntüleri ve meteoroloji istasyonlarının verilerinden elde edilen mekânsal veriler coğrafi bilgi sistemleri kullanılarak analiz edilmiş, sonuç harita ve çıktılar oluşturulmuştur. Elde edilen veriler sonucunda taşkının oluşmasında kısa sürede gelişen kuvvetli sağanak yağışların yanında havzadaki hızı yapılaşma sonucunda doğal sızma ve eğim koşullarının değiş̧mesi, taşkın koruma yapılarının işlevini yitirmesi, düdenlerin tıkanması ya da beton kuyulara dönüştürülmesi etkili olmuştur. Taşkın oluşumunu tetikleyen bu yanlış arazi uygulamaları devam ettiği sürece taşkının tekrarlanabileceği sonucuna varılmıştır.

Anahtar kelimeler: Taşkın, Gölova, Hatalı Arazi Kullanımı, Kayaköy Polyesi, Fethiye

\section{ABSTRACT}

Kayaköy Polje is a typical karst depression $6 \mathrm{~km}$ south of the city of Fethiye, extending for a length of $5 \mathrm{~km}$, with a width of $2 \mathrm{~km}$, and covering an area of 5 $\mathrm{km}^{2}$ at $140 \mathrm{~m}$ from the sea level. On January 31, 2019, heavy rainfall occurred in Fethiye, which is on the southwestern coast of Turkey, flooding settlements and agricultural areas on the nearby Kayaköy Polje. Following the process whereby a flood escalates into a disaster, a study was performed to investigate the roles of precipitation, karst processes, and land use, and solutions were proposed. Within the scope of the land surveying work that followed, the spatial information obtained with the help of drones, satellite images, and data collected by meteorological stations were analyzed using geographic information systems to create maps and other outputs. These findings implicated rapid development in the basin, in addition to the strong torrents that accelerated in a very short time, causing flooding in the region. The development activities altered the natural drainage and slope conditions, rendering flood protection structures useless, clogging sinkholes, or turning them into concrete wells. It was concluded that as long as improper land use, which triggered the flood, continued, flood and other disasters were bound to repeat.

Keywords: Flood, Polje, Improper Land Use, Kayaköy Polje, Fethiye

Başvuru/Submitted: 01.06.2020 • Revizyon Talebi/Revision Requested: 24.08.2020 • Son Revizyon/Last Revision Received: 01.09 .2020 • Kabul/Accepted: 30.09 .2020 - Online Yayın/Published Online: 23.11 .2020

\section{Sorumlu yazar/Corresponding author: Cihan BAYRAKDAR / cihanbyr@istanbul.edu.tr}

Atıf/Citation: Bayrakdar, C., Doker, M. F. \& Keserci, F. (2020). Polyelerde hatalı arazi kullanımların sebep olduğu afetlere bir örnek: 31 Ocak 2019 Kayaköy Polyesi Taşkını. Cografya Dergisi, 41, 109-128. https://doi.org/10.26650/JGEOG2020-0046 


\section{EXTENDED ABSTRACT}

Kayaköy Polje is a typical karst depression $6 \mathrm{~km}$ south of the city of Fethiye, extending for a length of $5 \mathrm{~km}$, with a width of $2 \mathrm{~km}$, and covering an area of $5 \mathrm{~km}^{2}$ at $140 \mathrm{~m}$ from the sea level. Formed inside the dolomite formation, it has a karst drainage system. Kayaköy Polje basin covers an area of $43 \mathrm{~km}^{2}$ including the Ovacık-Hisarönü plains to the east. Its waters drain outside through two ponors to the west side of the polje. On January 27, 2019, a cyclone system of North Atlantic origin developed and moved toward the Mediterranean Basin, collecting moisture along the way through interaction with warm sea waters, eventually initiating a downpour on the South Aegean line between January 31 and February 1 of 2019. The heavy rainfall $(170 \mathrm{~mm})$ in Fethiye and its immediate surroundings on these dates caused small-scale flooding in the region; however, its destructive impact peaked to reach proportions of a disaster in the Kayaköy Polje. In the aftermath of the heavy rainfall, 110 hectares of agricultural land and settlement areas were flooded for several months.

Within the scope of the land surveying work that followed, the spatial information obtained with the help of drones, satellite images, and data collected by meteorological stations were analyzed using geographic information systems to create maps and other outputs. The image classification work performed to track the changes in land use and land cover in the basin over time involved using Landsat satellite images from four different periods. They consist of Landsat 5 TM for the years 1985, 1995, and 2005, and Landsat 8 OLI/TIRS for 2019. Similarly, $10 \mathrm{~m}$ terrestrial resolution Sentiel-2 satellite data from February 4, March 16, and April 30, 2019 were analyzed using image enhancement techniques to study the effects of the flood.

Kayaköy Polje basin has been an area of intensive human activity in all periods. Its fertile soil provides favorable conditions for agricultural activities. Moreover, being home to several civilizations throughout its history, the basin has turned into a hotspot of tourist activities. While the basin floor was used only for agriculture in the past, it has been opened to settlements in modern times, causing serious problems such as floods. An analysis of the land cover and land use maps obtained from satellite imaging shows that the settlement area in the basin grew by almost six times after 1985, reaching a total area of 440 hectares.

These findings implicated rapid settlement development in the basin in addition to strong torrents that accelerated in a very short time, making this flood to be categorized as a natural disaster of hydrometeorological origin. A total precipitation of $588.2 \mathrm{~mm}$ was reported in December $(134.4 \mathrm{~mm})$ and January $(426 \mathrm{~mm})$, including the date of the flood incident and the pre-flooding period, which was effective at the onset of this process, and in February $(58.2 \mathrm{~mm})$ when the flood continued. This precipitation value shows that the climate during 2018-2019 was quite rainy compared with the corresponding period in previous years for the same region. For example, while the total precipitation in December, January, and February in 2015-2016 was $340.8 \mathrm{~mm}$, it was $353.6 \mathrm{~mm}$ in 2016-2017, 503.3 $\mathrm{mm}$ in 2017-2018, and $364.8 \mathrm{~mm}$ in 2019-2020. As stated above, the precipitation for 2019 was reported to be $1047.1 \mathrm{~mm}$, which far exceeds the average rainfall value of $862 \mathrm{~mm}$ reported for many years both periodically and throughout the year. In this context, rainfall above seasonal averages as of October in the climate period 2018-2019 peaked in January and became one of the most significant factors in the occurrence of the flood incident. The constructions and settlement activities in the region altered the natural drainage and slope conditions, rendering flood protection structures useless, clogging ponors, or turning dolines into concrete wells. In consideration of the long time required for complete drainage of the polje, the full extent of the damage is far worse than observed. Following the flood of January 31, 2019, it was not possible to talk about normalization of life or economic activities in the Kayaköy Polje before April 2019.

Kayaköy Polje is an area with a high risk of flooding, as it lacks a superficial drainage system, and human activities in the catchment basin are rampant. Considering these risk factors, watershed rehabilitation and flood prevention structures can be constructed (transferring water out of the basin, creating small dams, creating new water escape areas with boreholes, reactivating closed sinkholes, and discharging the water in the base of the polje using motor pumps). Furthermore, existing ponors should be maintained and kept active, and relevant underground cracks and cavities should be identified using geophysical methods to form new water escape pathways for drainage. In the flooding period, the water accumulated in the polje floor can be drained from lower levels using motopumps. All these suggestions should be evaluated in coordination with public institutions and organizations legally authorized to implement measures against flood and to reclaim floodplains in the aftermath of a disaster. 
The ancient ghost town of Kayaköy itself, which saw settlements until as recent as the turn of the $20^{\text {th }}$ century, is a clear indication that settlements should be built on the slopes, not on the polje floor. However, following the migration of people between Greece and Turkey in the early $20^{\text {th }}$ century, in the absence of adequate regulations, new settlements have spread on the polje floor instead of the slopes, making present-day disasters inevitable. Therefore, in all types of natural disaster prevention measures, taking historical precedents into consideration appears to be the most rational and economic solution. 


\section{GÍRIŞ}

31 Ocak 2019 tarihli gazetelerde Anadolu Ajansı kaynaklı haberlerde 'Seydikemer'de kar, Fethiye'de yağmur yaşamı olumsuz etkiledi" başlığı altında "Sağanak yağışın etkili olduğu Fethiye ilçesinde dağlık kesimden inen sular, Kayaköy Mahallesi'ndeki tarım arazilerine doldu ve bazı evlerde su baskınına yol açtı" şeklinde haberler yapıldı (Şekil 1). Haberin devamında "Fethiye Meteoroloji Müdürlüğü yetkilileri, ilçede son 24 saatte metrekareye 110 kilogram yağmur düştüğünü ve bu yıl ocak ayında uzun yıllar ortalamasına göre, Fethiye'nin iki kat daha fazla yağış aldığını" belirtildi (www.haberturk.com, https://www.ntv.com.tr/).

Sel ve taşkınlar, neden oldukları can, mal ve geri kazanılması mümkün olmayan doğal kaynak kayıplarına bağlı olarak ülkemizde önemli derecede etkiye sahip olan afetlerdir. Meteorolojik koşullar ile doğrudan veya dolaylı olarak ilişkili olan doğal afetlerin tamamı, meteorolojik afetler veya meteorolojik karakterli doğal afet olarak adlandırılmaktadır. Sel ve taşkınlar da hidrometeorolojik kökenli doğal afetlerden olup, ani gelişen, geniş alanlara yayılabilen ancak yerleşim yerlerine ve tarım alanlarına en fazla zarar veren afetlerdendir (Özdemir, 2007; Özdemir ve Bayrakdar, 2007).

Sel ve taşkınlar meydana gelişleri, işleyişleri ve etkileri bakımından farklılık gösterir. Turoğlu ve Özdemir (2005), seli; genellikle bir kanala bağlı eğim yönünde yüksek enerjili ve kontrolsüz akışa sahip, tahrip gücü yüksek su kütlesi hareketi olarak tanımlarken, taşkını ise, su fazlasına bağlı, kıyılardan başlayarak düz ve çukur alanları kaplayan geçici göllenme ve su basması olarak tanımlamıştır (Turoğlu ve Özdemir, 2005). Sel ve taşkınlar Türkiye'nin genelinde sıklıkla karşılaşılan bir doğal afettir. Sel ve taşkınların mekansal yoğunluğuna bakıldığında Karadeniz Bölgesinin ilk sırada olduğunu görürüz (Yalçınlar, 1995; Zeybek, 1998; Şahin, 2002; Turoğlu ve Özdemir, 2005; Bahadır, 2014). Yine Doğu Anadolu Bölgesinde (Uzun, 1995; Kopar, Polat, Hadımlı ve Özdemir, 2005; Doğanay, Alım ve Altaş, 2006), Akdeniz Bölgesinde (Buldur, Pınar ve Başaran, 2007; Hazir, Akgül, Alkaya ve Dağdeviren, 2016; Bilici ve Everest, 2017; Fural ve Cürebal, 2017), İç Anadolu'da (Uşkay ve Aksu, 2002), Ege'de (Özdemir, 2006) ve Marmara Bölgesinde (Turoğlu, 2011; Özdemir ve Elbaşı, 2015) sel ve taşkın afetlerine farklı zaman aralıklarında rastlanılmıştır.

Kayaköy’de (Fethiye) 31 Ocak ve 1 Şubat 2019 tarihlerinde yaşanan olayı ise yukarıdaki tanımlamalardan yola çıkılarak hidrometeorolojik kökenli doğal afetlerden "taşkın" olarak nitelendirebiliriz. Fethiye ve yakın çevresinde 31 Ocak ve 1 Şubat 2019 tarihlerinde aşırı yağışlar $(170 \mathrm{~mm})$ bölgede sel ve taşkınlara sebep olsa da afet boyutuna ulaşacak en büyük etkiyi Kayaköy Polyesinde yarattığı taşkın ile göstermiştir (Şekil 2).

Kayaköy’de yaşanan bu afet bir karstik depresyon olan polyenin tabanında olmasından dolayı taşkının oluşumu ve etkilerinin ortadan kalkması bakımından diğer bölgelerden farklılıklar içermektedir. Jeomorfolojik açıdan polye karstik arazi içerisinde, en az bir yamacı kireçtaşından oluşan, düz, alüvyal dolgulu, karstik drenaja sahip ve oluşumunda tektonizmanın da etkili olduğu büyük kapalı depresyonları ifade etmektedir (Erinç, 1971; Gams, 1978, 2005;

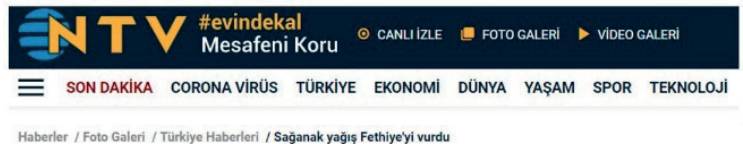

\section{Sağanak yağış Fethiye'yi vurdu}

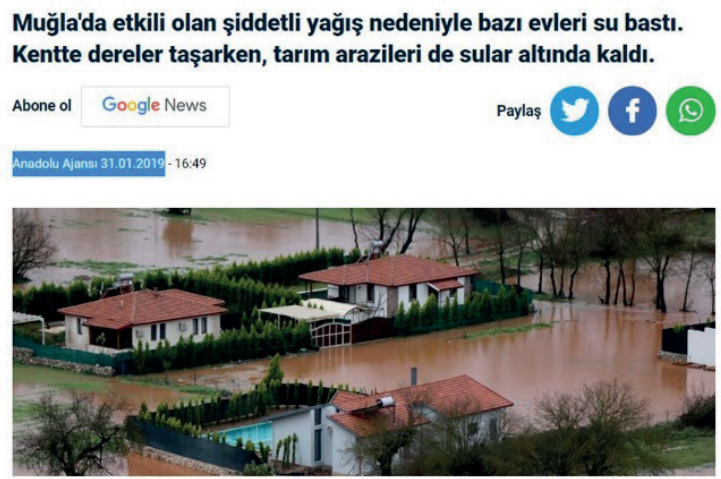

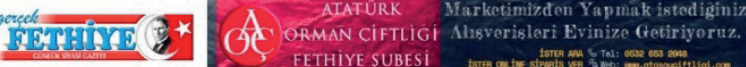

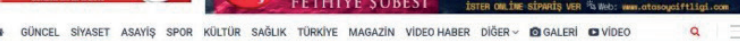

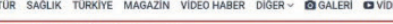
Fethiye'de sel baskını

| Muğla'nın Fethiye ilçesinde, geceden itibaren etkill olan sağanak yağıș bazı evlerin bodrum katlarını tarım arazilerini su altında bıraktı.

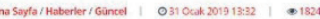

HABER

\begin{tabular}{l|l|l|l|l|l} 
URK SON DAKIKA GÜNDEM EKONOMI SPOR MAGAZIN KADIN SAĞLIK &
\end{tabular}

\section{Seydikemer'de kar, Fethiye'de yağmur yașamı} olumsuz etkiledi

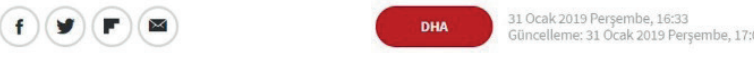

MUĞLA'nın Seydikemer ilçesi Karabel mevkisinde kar, Fethiye'de ise sağanak yağış etkili oldu. Fethiye'de zemin katta kalan ev ve iş yerlerinde su baskınları meydana gelirken, FethiyeAntalya karayolunun Karabel mevkisindeki kar yağısıı nedeniyle ulaşım kontrollüi sağlanmaya başladı.

Şekil 1: Kayaköy Taşkınına ilişkin yerel ve ulusal basındaki çevrimiçi haberler (www.haberturk.com, www.ntv.com.tr, gercekfethiye.com). Figure 1: Online news of the Kayaköy flood in local and national media((www.haberturk.com, www.ntv.com.tr, gercekfethiye.com). 

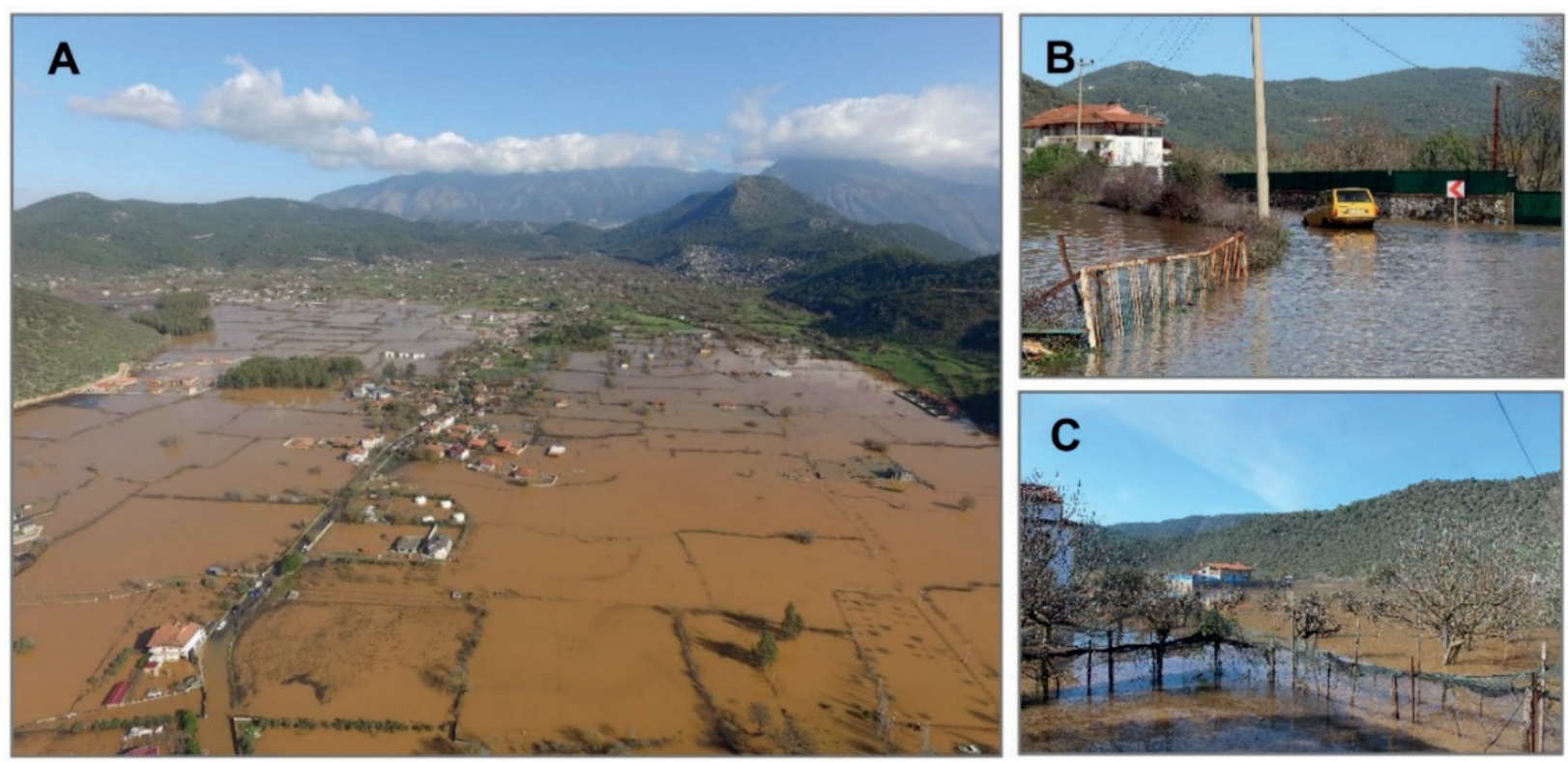

Şekil 2: Kayaköy Polyesi taşkınına batıdan bakış ve geride Kayaköy Havzası'nın doğu sınırını oluşturan yüksek kütle Babadağ (A), Taşkın sırasında su altında kalan konut, yol (B) ve tarım alanları (C) (3 Şubat 2019).

Figure 2: Western view of the Kayaköy Polje with the Babadağ (A) elevation forming the eastern border of the Kayaköy basin in the background. Flooded residential areas, roads (B), and agricultural land (C) (February 3, 2019).

Jennings, 1985; Ford \& Williams, 2007; Şimşek, Doğan ve Öztürk, 2020). Zaman zaman polye tabanı ya da kenarındaki düdenler bitki parçaları gibi çeşitli malzemeler veya kil ile tıkanabilir bu da polye tabanında geçici/kalıcı göl oluşumu sağlar (Bonacci, 2013). Bu nedenle bu tür polyeler "Gölova" olarak adlandırılırlar (İzbırak, 1977; Doğan, 1996). Bu tanımdan da anlaşılacağı üzerine polye tabanlarında geçici göllerin varlığı doğal bir sürecin sonucu olsa da zaman zaman bu göl sınırları beklenenden daha geniş alanları hatta tüm polye tabanını işgal edebilmektedir. Bu durum aşırı yağışların sonucu olabileceği gibi polye tabanlarındaki doğal su batanların tıkanması ya da bu düdünlere insan müdahaleleri de olabilmektedir. Polyeler genellikle çıplak kayaların yaygın olduğu, bitkilerinin baskın olmadığı, toprak oluşumunun zayıf olduğu karstik bölgelerde çevreden taşınan alüvyal malzeme ve terra-rossa ile kaplı tabanı düz ve verimli alanlardır. Bu özelliği nedeniyle karstik bölgelerde ekonomi ve kalkınma için oldukça önemli alanlardır. Bu nedenle polye tabanlarında oluşan bu taşkınlar can, mal ve geri kazanılması mümkün olmayan doğal kaynak kayıplarına sebebiyet verebilmektedirler.

Çalışma konusunu teşkil eden Kayaköy Polyesi de tarımsal ve turizm faaliyetlerinin yoğun olarak yapıldığ ülke ekonomisine katma değeri fazla olan bir sahadır. Akdeniz Bölgesi'nin Teke Yöresinde yer alan Kayaköy Polyesi, Muğla'nın Fethiye ilçesinin $5,5 \mathrm{~km}$ kadar güneydoğusunda deniz seviyesinden $140 \mathrm{~m}$ yüksekte, $5 \mathrm{~km}$ uzunluğunda ve $2 \mathrm{~km}$ kadar eninde bir karstik depresyondur (Şekil 3).
Kayaköy Polyesi'nin güneydoğu yamacında yer alan "Kayaköy Örenyeri” Antik Dönemde "Karmylassos" olarak bilinmekte olup Kayaköy'deki ilk izler antik Likya uygarlığına aittir. Kayaköy ve çevresinde sırasıyla Likyalılar'dan sonra, Makedonyalılar, Romalılar, Rumlar yaşamıştır. 1284 yılında Menteşeoğulları'nın eline geçen yöre, 1424 yılında Osmanlı topraklarına katılmıştır (Akşit, 1967). Türkiye Cumhuriyeti'nin Kuruluş yıllarında bölgede yaşayan Rumların Batı Trakya'daki Türkler ile mübadele edilmesi sonucu boşaltılan kentteki yapıların ahşap olan kapı pencere ve üst örtü sistemlerinin doğal etkenler ile tahrip olmasıyla kent hayalet bir şehir görünümü almıştır. Terk edilen kentte kullanıldığı dönemde her biri $50 \mathrm{~m}^{2}$ 'den büyük olmayan 350 ila 400 konut bulunmaktadır. Konutların yanı sıra evlerin arasına serpiştirilen çok sayıda şapel, 2 büyük kilise, 1 okul binası ile 1 gümrük binası yer almaktadır (https://www.kulturportali.gov.tr/turkiye/mugla/ gezilecekyer/kayakoy).

Bu çalışmada 31 Ocak 2019 tarihinde Kayaköy Polyesi'nde yaşanan ve etkisi birkaç ay süren taşkının oluşması ve afete dönüşmesindeki nedenler araştırılmıştır. Taşkının meydana gelmesinde ve afete dönüşmesinde yağış faktörü ile birlikte havzanın yapısal özelliklerinin özellikle karstik süreçlerin ve taşkın sahasındaki arazi kullanım özelliklerinin etkilerini araştırmak ve çözüm önerileri getirmek bu çalışmanın temel hedefini oluşturmuştur. 

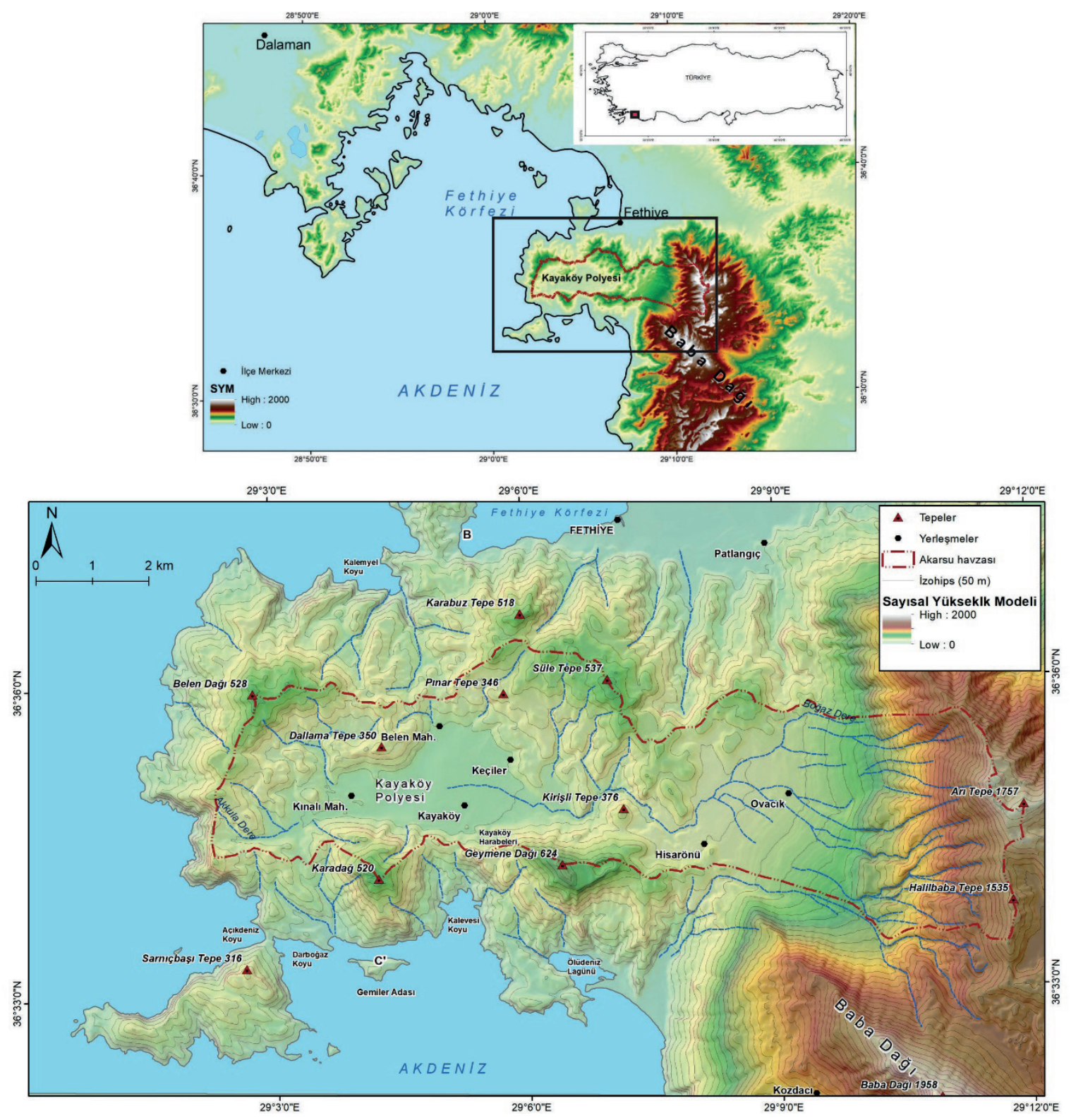

Şekil 3: Kayaköy Polyesi ve yakın çevresinin lokasyon özellikleri.

Figure 3: Location characteristics of the Kayaköy Polje and immediate surroundings.

\section{MATERYAL VE METOT}

Çalışmanın veri kaynaklarını, 1:25,000 ölçekli topografya haritaları, 1:25,000 ölçekli jeoloji haritaları, uydu görüntüleri, insansız hava araçları (IHA) ile elde edilen görüntüler ve 2 Şubat 2019 tarihinde yapılan arazi çalışmaları sonucunda üretilen haritalar oluşturmaktadır. Klimatolojik analizler için gerekli veriler Meteoroloji İşleri Genel Müdürlüğü’nden elde edilmiştir.

Havzanın geçmişten günümüze arazi örtüsü ve kullanımı değişiminin belirlenebilmesi için yapılan görüntü sınıflandırma işleminde 4 farklı döneme ait Landsat uydu görüntüleri kullanılmıştır. Bu görüntüler, 1985, 1995 ve 2005 yılları için Landsat 5 TM, 2019 için Landsat 8 OLI/TIRS görüntülerinden oluşmaktadır. Uydu verileri seçilirken, geçmişten günümüze zaman serisi oluşturulabilmesi, arazi örtüsü ve kullanım türlerini ayırt edilebilecek gerekli çözünürlüğe sahip olmas1, sınıflandırmanın doğru sonuç verebilmesi adına aynı mevsime ait olması ve \%10'dan daha az bulutluluk oranına sahip olması gibi kriterler göz önünde bulundurulmuştur. Havza içerisindeki arazi örtüsü ve kullanım değişiminin en iyi şekilde ortaya konması adına, sınıflandırma işleminde kısa dalga, kızıl ötesi ve kırmızı bant kombinasyonları tercih edilmiştir (Esri, 2020). Böylelikle görüntü işleme analizine hazır hale getirilen uydu 
Tablo 1: Doğruluk Analiz Sonuçları (A:1985) (B:1995) (C:2005) (D:2019).

Table 1: Results of the Accuracy Analysis (A:1985) (B:1995) (C:2005) (D:2019).

\begin{tabular}{|c|c|c|c|c|c|c|c|c|c|c|c|c|c|c|c|c|c|c|c|c|c|}
\hline \multirow{2}{*}{\multicolumn{2}{|c|}{$A$}} & \multicolumn{9}{|c|}{ Referans Görüntü } & \multirow{2}{*}{\multicolumn{2}{|c|}{$\mathrm{B}$}} & \multicolumn{9}{|c|}{ Referans Görüntü } \\
\hline & & \multirow{2}{*}{\begin{tabular}{|c} 
Yerleşme \\
9
\end{tabular}} & \multirow{2}{*}{$\begin{array}{c}\begin{array}{c}\text { Tarımsal } \\
\text { Arazi }\end{array} \\
1\end{array}$} & \multirow{2}{*}{ Orman } & \multirow{2}{*}{$\frac{\text { Maki }}{0}$} & \multirow{2}{*}{$\begin{array}{c}\text { Çıplak } \\
\text { Arazi }\end{array}$} & \multirow{2}{*}{$\frac{\text { Deniz }}{0}$} & \multirow{2}{*}{$\begin{array}{r}\text { Toplam } \\
10\end{array}$} & \multirow{2}{*}{\begin{tabular}{|c|}
$\begin{array}{c}\text { Kullanıcı } \\
\text { Doğruluğu }\end{array}$ \\
0.9 \\
\end{tabular}} & Kappa & & & \multirow{2}{*}{\begin{tabular}{|c} 
Yerleşme \\
7
\end{tabular}} & \multirow{2}{*}{$\begin{array}{c}\text { Tarımsal } \\
\text { Arazi }\end{array}$} & \multirow{2}{*}{$\begin{array}{c}\text { Orman } \\
0\end{array}$} & \multirow{2}{*}{$\frac{\text { Maki }}{0}$} & \multirow{2}{*}{$\begin{array}{c}\text { Çiplak } \\
\text { Arazi } \\
0\end{array}$} & \multirow{2}{*}{$\frac{\text { Deniz }}{0}$} & \multirow{2}{*}{$\begin{array}{c}\text { Toplam } \\
10\end{array}$} & \multirow{2}{*}{\begin{tabular}{|c|}
$\begin{array}{c}\text { Kullanıcı } \\
\text { Doğruluğu }\end{array}$ \\
0.7 \\
\end{tabular}} & Kappa \\
\hline \multirow{9}{*}{ 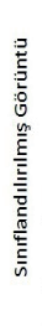 } & Yerleşme & & & & & & & & & & \multirow{9}{*}{ 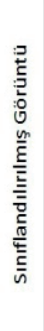 } & Yerleşme & & & & & & & & & \\
\hline & Tarımsal Arazi & 4 & 29 & 0 & 0 & 0 & 0 & 33 & 0.87 & & & Tarımsal Arazi & 3 & 28 & 0 & 0 & 4 & 0 & 31 & 0.9 & \\
\hline & Orman & 0 & 0 & 83 & 0 & 9 & 1 & 93 & 0.89 & & & Orman & 0 & 0 & 81 & 8 & 0 & 0 & 93 & 0.87 & \\
\hline & Maki & 0 & 0 & 5 & 50 & 14 & 0 & 69 & 0.72 & & & Maki & 0 & 0 & & 57 & 8 & 0 & 65 & 0.87 & \\
\hline & Çıplak Arazi & 0 & 0 & 0 & 4 & 12 & 0 & 16 & 0.75 & & & Çıplak Arazi & 0 & 0 & 0 & 3 & 16 & 0 & 19 & 0.84 & \\
\hline & Deniz & 0 & 0 & 1 & 0 & 0 & 85 & 86 & \multirow[t]{2}{*}{0.98} & & & \multirow{2}{*}{$\begin{array}{c}\text { Deniz } \\
\text { Toplam }\end{array}$} & 0 & 0 & & 0 & 1 & 83 & 85 & 0.97 & \\
\hline & Toplam & 13 & 30 & 89 & 54 & 35 & & 307 & & & & & 10 & 31 & 82 & 68 & 29 & 83 & 303 & \multirow[b]{2}{*}{0.89} & \\
\hline & $\begin{array}{c}\text { Üretici } \\
\text { Doğruluğu }\end{array}$ & 0.69 & 0.96 & 0.93 & 0.92 & 0.34 & 0.98 & & 0.87 & & & $\begin{array}{c}\text { Üretici } \\
\text { Doğruluğu }\end{array}$ & 0.7 & 0.9 & 0.98 & 0.83 & 0.55 & 1 & & & \\
\hline & Kappa & & & & & & & & & 0.83 & & Kappa & & & & & & & & & 0.86 \\
\hline & & & & & & rans Göri & & & & & & & & & & & rans Gör & & & & \\
\hline & & Yerleşme & $\begin{array}{c}\text { Tarımsal } \\
\text { Arazi } \\
\end{array}$ & Orman & Maki & $\begin{array}{l}\text { Çıplak } \\
\text { Arazi }\end{array}$ & Deniz & Toplam & \begin{tabular}{|c|} 
Kullanıcı \\
Doğruluğu
\end{tabular} & Kappa & & & Yerleşme & $\begin{array}{c}\text { Tarımsal } \\
\text { Arazi } \\
\end{array}$ & Orman & Maki & $\begin{array}{c}\text { Çiplak } \\
\text { Arazi } \\
\end{array}$ & Deniz & Toplam & \begin{tabular}{|c|} 
Kullanıcı \\
Doğruluğu \\
\end{tabular} & Kappa \\
\hline & Yerleşme & 11 & 0 & 0 & 0 & 0 & 0 & 11 & & & & Yerleşme & 16 & 0 & 0 & 1 & 0 & 0 & 17 & 0.94 & \\
\hline & Tarımsal Arazi & 3 & 25 & 0 & 0 & 0 & 0 & 28 & & & $\exists$ & Tarımsal Arazi & 3 & 19 & 1 & 0 & 0 & 0 & 23 & 0.82 & \\
\hline 气 & Orman & 2 & 0 & 99 & 12 & 2 & 0 & 115 & & & $\tilde{E}$ & Orman & 0 & 0 & 85 & 7 & 3 & 0 & 95 & 0.89 & \\
\hline :0 & Maki & 0 & 0 & 2 & 37 & 5 & 0 & 44 & & & : & Maki & 2 & 0 & 0 & 53 & 4 & 0 & 59 & 0.89 & \\
\hline$\frac{m}{\varepsilon}$ & Çıplak Arazi & 0 & 0 & 0 & 0 & 17 & 0 & 17 & & & $\frac{m}{\varepsilon}$ & Çıplak Arazi & 0 & 0 & 0 & 1 & 19 & 0 & 20 & 0.95 & \\
\hline 늘 & Deniz & 0 & 0 & 0 & 0 & 0 & 85 & 85 & & & 늘 & Deniz & 0 & 0 & 0 & 0 & 1 & 85 & 86 & 0.98 & \\
\hline$\overline{\bar{z}}$ & Toplam & 16 & 25 & 101 & 49 & 24 & 85 & 300 & & & $\overline{\bar{z}}$ & Toplam & 21 & 19 & 86 & 62 & 27 & 85 & 300 & & \\
\hline$\frac{\frac{\pi}{4}}{\frac{5}{5}}$ & $\begin{array}{c}\text { Üretici } \\
\text { Doğruluğu }\end{array}$ & 0.7 & 0.9 & 0.98 & 0.75 & 0.7 & 1 & & 0.91 & & $\frac{\bar{c}}{\frac{c}{E}}$ & $\begin{array}{c}\text { Üretici } \\
\text { Doğruluğu }\end{array}$ & 0.76 & 1 & 0.98 & 0.85 & 0.7 & 1 & & 0.92 & \\
\hline & Kappa & & & & & & & & & 0.88 & & Kappa & & & & & & & & & 090 \\
\hline
\end{tabular}

verilerinden obje tabanlı görüntü sinıflandırma yöntemleri kullanılarak arazi örtüsü ve kullanım haritaları üretilmiştir. Obje tabanlı sınıflandırma, piksel tabanlı sınıflandırma yöntemlerinden farklı olarak görüntünün analiz edilmesinde doku, şekil, boyut ve komşuluk ilişiklerini de dikkate alması sınıflandırma doğruluğunu arttıran bir yöntem olarak dikkat çeker (Lu ve Weng, 2007). Görüntü sinıflandırmada obje tabanlı sınıflandırma yöntemlerinin uygulanmasında ArcGIS Pro 2.5.0 yazılımı kullanılmıştır. Elde edilen arazi örtüsü ve kullanımı, haritaların doğruluk analizinde 1985,1995,2005 yıllarına ait görüntüler için tarihsel topografya haritaları kullanılırken, 2019 yılı için ise yüksek çözünürlüklü uydu verileri ile arazi çalışmaları referans alınmıştır. Doğruluk analizleri uzaktan algılamada görüntü sınıflandırma analizinin hassasiyetini belirlemek için kullanılır (Congalton ve Green, 2009). Bu çalışmada doğruluk analizi tabakalı rastgele örnekleme (Stratified Random Point) tekniği ile belirlenen ortalama 300 nokta ile yapılmıştır. Bu nokta dağıtım modeli çalışma alanında en fazla alan kaplayan sınıfa daha fazla nokta atma prensibine dayanmaktadır (Banko, 1998). Çalışma kapsamında sınıflandırılmış görüntüler için kullanıcı doğruluğu (görev hatası), üretici doğruluğu (ihmal hatası) ve Kappa oran1 hesaplanmıştır (Tablo 1). 31 Ocak 2019 tarihinde meydana gelen taşkının izlerinin ortaya konması için 04 Şubat, 16 Mart ve 30 Nisan 2019 tarihlerine ait 10 metre yersel çözünürlüklü Sentiel-2 uydu verisi görüntü zenginleştirme teknikleri ile analiz edilmiştir. Su yüzeylerinin tespitinde yeşil banttaki bir su kütlesinin yansıtıcılı̆̆ını en üst düzeye çıkarmak için yeşil ve kızılötesi bantlarını kullanarak normalleştirilmiş fark su indeksi (NWDI) kullanılabilmektedir (McFeeters, 1996). Ancak bu zaman zaman topraktaki nem ile su yüzeylerini karıştırabilmektedir. Bu nedenle NDWI'de kullanılan kızılötesi bandı kısa dalga kızılötesi ile değiştirilerek yeni bir normalleştirilmiş fark su indeksi (MNDWI) üretilmiş̧ir (Xu, 2006). Bu çalışmada taşkın etki sahasının tespiti için Sentiel-2 uydu verilerine MNDWI görüntü zenginleştirme tekniği uygulanmıştır.

\section{BULGULAR}

\subsection{Jeoloji}

Çalışma sahası Kuzey- Kuzeybatı yönünden, Orta Miyosende Beydağları otoktonu üzerine yerleşmiş olan Likya napları içerisinde yer alan Bodrum napı içerisinde yer alır (Şenel, 1997). Bodrum napındaki Orta Triyas-Liyas yaşlı karbonatlardan oluşan formasyon "Kayaköy dolomiti" olarak adlandırılmıştır. Birimde karstlaşma yaygındır. Kayaköy Polyesi'nin batısında çörtlü kireçtaşı ara seviyeli dolomit, dolomitik kireçtaşlarından oluşan Sandak formasyonu (Orta Jura) yer alır. Kayaköy Havzası'nın doğusunda $1958 \mathrm{~m}$ seviyelerine oluşan yüksek dağlık kütle 
Babadağ Formasyonu olarak adlandırılan çörtlü kireçtaşlarından oluşurken (Şekil 4) Kayaköy Havzası'nın merkezinde havzanın daraldığ1 ve boğaz oluşturduğu kısımda Faralya Formasyonu olarak adlandırılan bazik volkanit, breş, kumtaşı vb. kaya türleri gözlemlenir (Şenel, 1997).

Kayaköy Polyesi Fethiye-Burdur Fay zonu içerisinde kalır. Fethiye-Burdur arasında KD- yönünde yaklaşık olarak 300 km'lik bir uzanım gösteren Burdur fayı, çoğu yerde sol-oblik atım özelliği gösteren ve günümüzde hala aktif olan bir fay zonundan oluşur. Çalışma sahasına en yakın ve en büyük deprem olan 1957-Fethiye depremi (25.04.1957) Fethiye Körfezinin güneybatısında Rodos'un doğusunda, meydana gelmiştir (Bozcu, Yağmurlu ve Şentürk, 2007).

\subsection{Jeomorfoloji}

Kayaköy Yarımadası'nın merkezinde tipik dış drenaja kapalı bir karstik depresyon olan (Avşarcan, 1992) Kayaköy Polyesi, Nazik (2004) tarafından Toros Dağları Karst Bölgesi’nin alt alanı
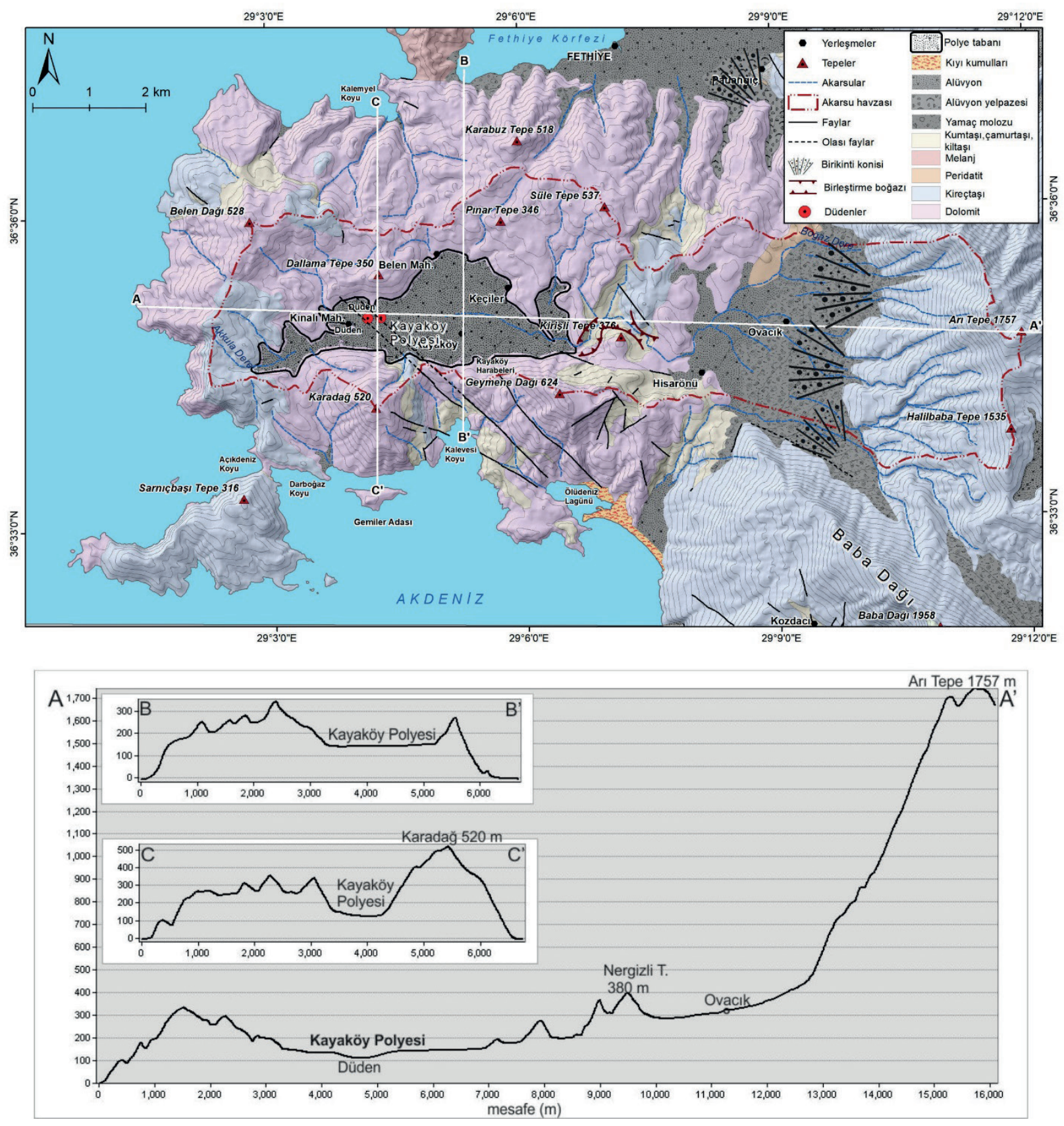

Şekil 4: Kayaköy Polyesi ve çevresinin jeomorfolojik özellikleri.

Figure 4: Geomorphological characteristics of the Kayaköy Polje and immediate surroundings. 
olan ve sığ karstın karakteristiği olan polyelerin görüldüğü (gölovalar) Batı Toros Karst alanı içerisinde tanımlanmıştır. Yine Kayaköy Polyesi, oluşumunda büyük ölçüde jeolojik kontrolün baskın olması ve faylarla sınırlandırılmış olmasından dolayı polye sınırflandırması içinde (Ford ve Williams, 1989; 2007; Şimşek, Doğan ve Öztürk, 2020) yapısal polye olarak tanımlanabilir.

Batı Torosların batı ucunda bulunan ve kuzeyi (Fethiye Körfezi), doğusu ve güneyi (Ölüdeniz Lagünü) Akdeniz ile çevrili yarımadanın merkezinde deniz seviyesinden $140 \mathrm{~m}$ yüksekte olan Kayaköy Polyesi'nin de güneyinde Geymene Dağı (624 m), Karadağ (520 m), kuzeyinde ise Belen Dağı (528 m), Süle Tepe $(537 \mathrm{~m})$ yer alır. Kayaköy Polyesi su toplama havzası ise $43 \mathrm{~km}^{2}$ alan kaplayıp doğuda yer alan OvacıkHisarönü ovalarını da kapsar. Su toplama havzasının en doğusunda Arı Tepe (1757 m) ve Halilbaba Tepe (1535 m) gibi yüksek kısımlar yer alır (Şekil 4).
İçerisinde Kayaköy Polyesi'nin yer aldığ 1 Kayaköy Yarımadas1, ortalama yükseltisi $350 \mathrm{~m}$ olan bir plato karakterindedir. Hafif dalgalı düzlükler ve üzerinde yüksek tepelerin yeraldığ 1 bu karstik plato yer yer akarsularca derince yarılmıştır (Biricik, Bozyiğit ve Kurt, 1998). Yarımada'nın kıyıları büyük ölçüde falezli kıyılardan oluşmakla birlikte yarımada'nın güneydoğusunda ülkemizin en bilindik lagünlerinden biri olan Ölüdeniz Lagünü yer alır (Güneysu, Ozaner ve Erkal, 1996).

Kabaca doğu - batı uzanışlı Kayaköy Polyesi 5 km uzunluğunda, $2 \mathrm{~km}$ eninde ve $5 \mathrm{~km}^{2}$ alana sahiptir. Polyenin güney sınırı doğu-batı doğrultusunda çizgisel bir uzanış gösterirken kuzey sınırı Belen Mahallesi kısmında kuzeye doğru genişler. 140 m yüksekliğe sahip polye tabanının çevresi 520-624 m arasındaki yükseklikteki tepelerle çevrilidir ve polye çanağının en alçak eşiği $175 \mathrm{~m}$ ile polyenin güneybatısındadır (Şekil 4).

N"

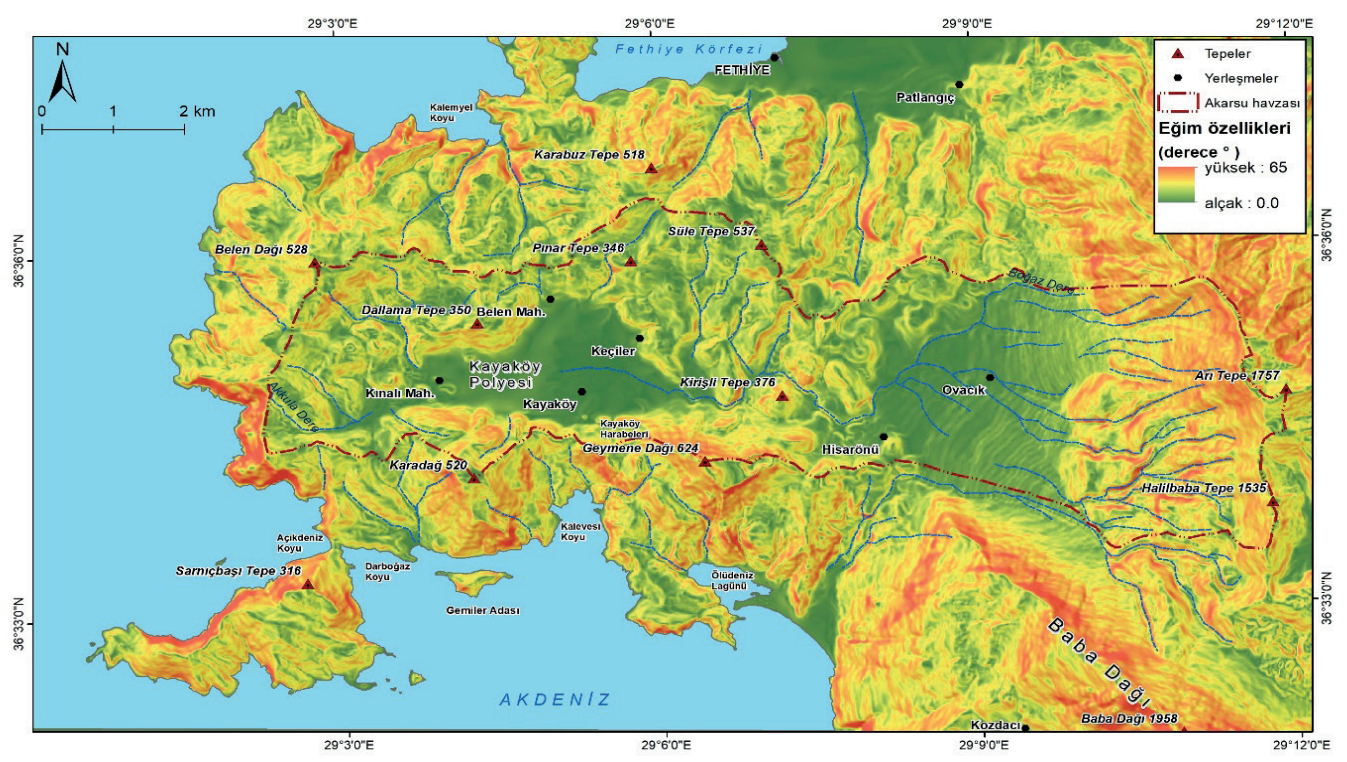

Şekil 5: Kayaköy Polyesi ve çevresinin eğim özellikleri.

Figure 5: Slope characteristics of the Kayaköy Polje and immediate surroundings.
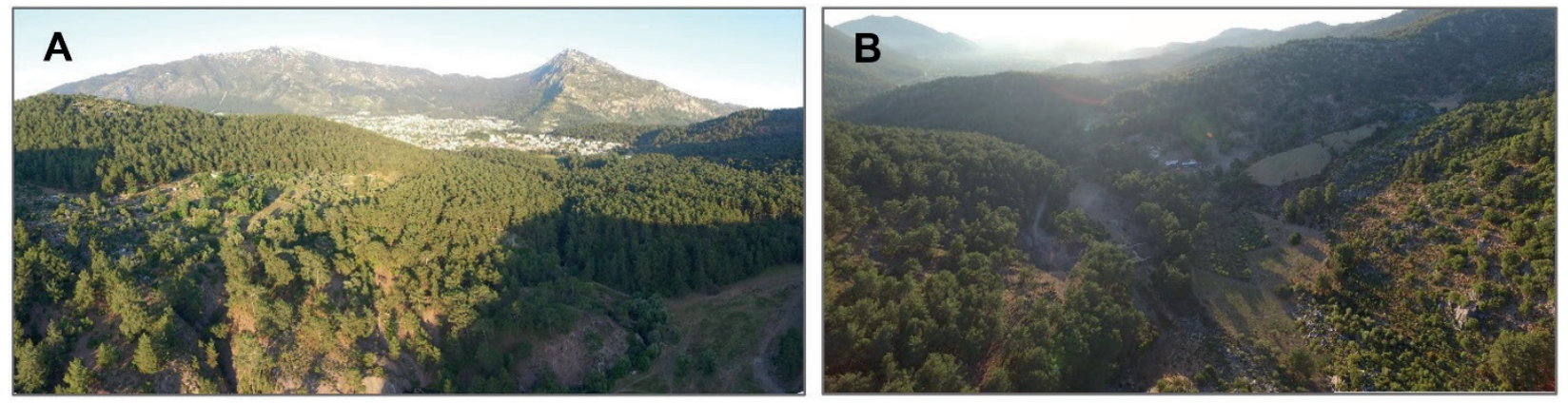

Şekil 6: Hisarönü Kayaköy Polyesi arasındaki birleştirme boğazından doğuya Hisarönüne bakış (A) ve boğazdan batıya Kayaköy Polyesi'ne bakış (B). Figure 6: View of Hisarönü in the east from the gorge between the Hisarönü Kayaköy Polje (A) and view of the Kayaköy Polje from the gorge in the west (B). 
Polye havzasındaki en yüksek kesimler ise doğuda yer alır. Bu kısımda 1757 m yükseltiye sahip Arı Tepe'nin havzaya bakan yamacı oldukça dik (büyük kısmı $45^{\circ}$ üzerinde yer yer $65^{\circ}$ eğim) olup karstik kuru vadilerce yarılmıştır (Şekil 4, 5). Yamacın eteklerinde ise yüksek eğimli $\left(20-30^{\circ}\right)$ birikinti konileri ve önlerinde daha düşük eğimli (10-20 $)$ alüvyal yelpazeler yer alır. $\mathrm{Bu}$ alüvyal yelpazelerin oluşturduğu eğimli saha Ovacık yerleşmesi boyunca devam ederek Hisarönü'ne kadar devam eder (Şekil 4, 5). Bu kısımda Ovacık yerleşmesi birikinti yelpazesi üzerinde kurulmuşken onun batısındaki Hisarönü ise flüvyokarstik bir depresyon tabanında yer alır. Bu alan Kirişli ve Nergizli Tepe civarında bazik volkanit, breş, kumtaşı içerisinde açılan bir birleştirme boğazı ile Kayaköy Polyesi'ne yüzeysel drenajla bağlanmaktadır (Şekil 4, 6).

Polye yamaçlarından kısa boylu mevsimlik dereler polye tabanına doğru yöneliriler. Polye tabanında genel eğim ise batı yönündedir. Polyenin batısında, Kınalı Mahalle yakınlarında iki düden polye sularının dışarıya drene olmasını sağlamaktadır (Avşarcan, 1992). Bu düdenler polyenin en alçak kısmında yer almakta olup güneyde polyeyi güneydoğu- kuzeybatı yönlü kesen fayların uzanış doğrultusunda yer almaktadırlar. Faylar nedeniyle meydana gelen kırık ve çatlak sistemleri bu düdenlerin oluşmasındaki en temel faktör olarak değerlendirilebilir (Şekil 4).

\section{3. İklim}

Akdeniz havzası genel itibari ile Orta kuşak'ta, güneyde sutropikal basınç alanları ile kuzey ve kuzeybatısında alçak basınç sitemlerinin kesiştiği ve bu basınç merkezlerinin zaman zaman havza üzerine hâkim olabildiği bir yapı arz eder. Çalışma sahası ve Akdeniz Havzası, mevsimlik yağış değişkenliğini yaratan genel atmosfer sirkülasyonu ile bağlantılı birkaç önemli atmosferik sisteme sahiptir (Cheyette, 2014). Bunlardan belki de en önemlisi Orta ve Kuzey Atlantik'deki Azor YB (Yüksek Basınç) alanı ve İzlanda AB (Alçak Basınç) alanları tarafından şekillendirilen Kuzey Atlantik'den Akdeniz Havzasına doğru gelişen firtına hatlarıdır. Özellikle kış ayları boyunca Atlantik'den Akdeniz havzasına doğru gelişen bu akış devamında Doğu Akdeniz'de doğu-kuzeydoğu yönüne hareket etme eğilimi göstermektedir (Flocas vd., 2010). Böyle bir durum ise nispeten soğuk karakterli hava kütlesi ile Akdenizin nispeten sıcak sularının etkileşime girerek kararsızlık koşullarını daha da fazla tetiklemek sureti ile kuvvetli konveksiyona ve sonucunda gökgürülttülü sağanak yağışlara sebebiyet verebilmektedir.

Batı Akdeniz bölümünde yer alan Kayaköy (Fethiye) ve çevresi konumu itibari ve yukarıda bahsedilen atmosferik sirkülasyon gereği Akdeniz iklim kuşağının tipik özelliklerini yansıtmaktadır. Çalışma sahasının kuş uçuşu 6 km kuzeyinde yer alan Fethiye meteoroloji istasyonunun 57 yıllık rasat verisi incelendiğinde bu özellikler açıkça görülebilmektedir (Şekil 7). İstasyon verileri incelendiğinde yıllık ortalama yağış miktarının $862 \mathrm{~mm}$, yıllık ortalama sıcaklık ortalamasının ise $18^{\circ} \mathrm{C}$ olduğu görülmektedir. Şekil 7'de görüldüğü üzere çalışma sahasında yıllık yağışın çok büyük bir bölümü sonbahar mevsiminin geç dönemleri ve kış ayları içerisinde düşmektedir. Kayaköy (Fethiye) ve Güneybatı Anadolu, Türkiye'ye ait iklimsel sınıflandırmalarda Akdeniz İklimi ile karakterize olur. İklim tipi

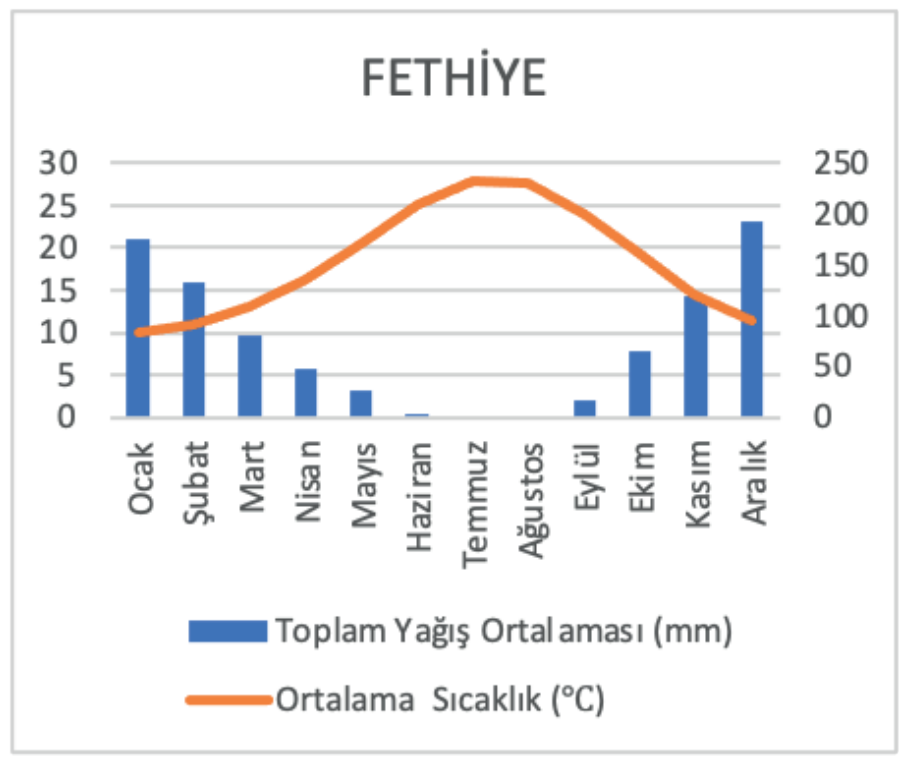

Şekil 7: Fethiye meteoroloji istasyonun 1960-2016 yılları arası (57 yıllık) ortalama sıcaklık ve yağış verileri.

Figure 7: Mean temperature and precipitation data provided by the meteorology station of Fethiye for the period from 1960 through 2016 (57 years).

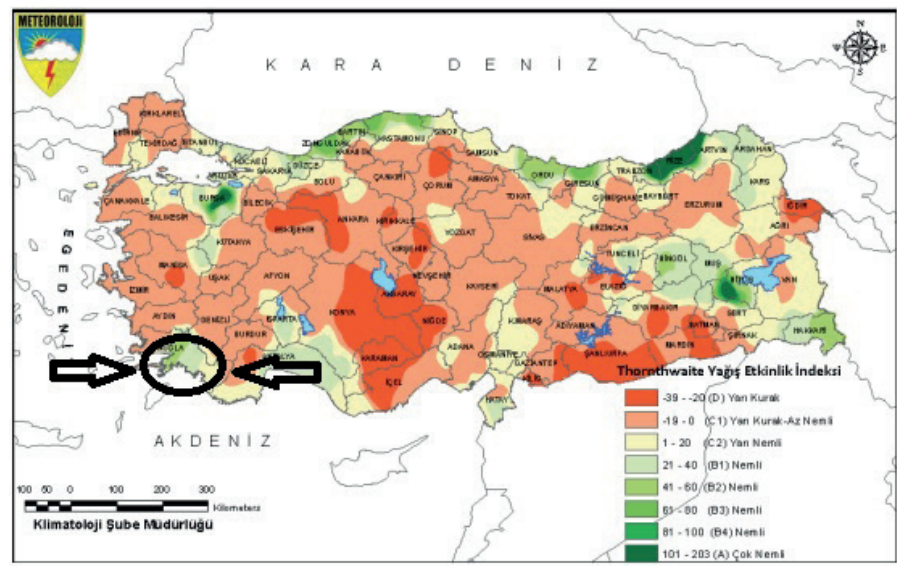

Şekil 8: Türkiye Thorntwaite yağış etkinlik indseksi ve Fethiye ve yakın çevresinin Türkiye özelinde konumu (MGM,2019).

Figure 8: Turkey Thorntwaite precipitation effectiveness index and the position of Fethiye and surroundings within Turkey (MGM, 2019). 
olarak yarı nemli (Erinç İndisi), step-nemli (De Martonne), yarıkurak, az nemli, mezotermal (Thornthwaite) olarak tanımlanmıştır (Şekil 8) (Yılmaz ve Çiçek, 2016; MGM, 2019). Yine Fethiye ve Batı Akdeniz Bölümü'nde gerçekleşen kış yağışlarının gelişen cephe hatları ile bağlantılı olarak yıllık ortalama yağışların önemli bir bölümü sağanak karakterli bir yap1 sergilemektedir. Bu tür yă̆ışlar kısa zamanlarda önemli miktarlarda yağışın gerçekleştiği anlamı da taşımaktadır. Sağanak karakterli yağışlar meydana geldiğinde yüzeye düşen yă̆ışın toprak ve yüzeyde yer alan malzemeler tarafindan emilme olasılığı da düşüktür. Buna bağlı olarak gerçekleşen yağış neredeyse tümüyle akışa geçebilmektedir.

Yukarıda bahsedilen sinoptik basınç deseninin, çalışma sahası ve çevresi için 27 Ocak 2019 tarihi itbari ile gelişmeye başladığını görebilmekteyiz (Şekil 9). Ortaya çıkan Kuzey Atlantik kökenli AB sistemi zamanla Akdeniz Havzası'na doğru hareket etmiş 31.01.2019 ile 01.02.2019 tarihleri arasında kuvvetli yağışlar meydana gelmesine neden olmuştur. Kısa süreçler içerisinde gelişen kuvvetli sağanak yağışlar beraberinde
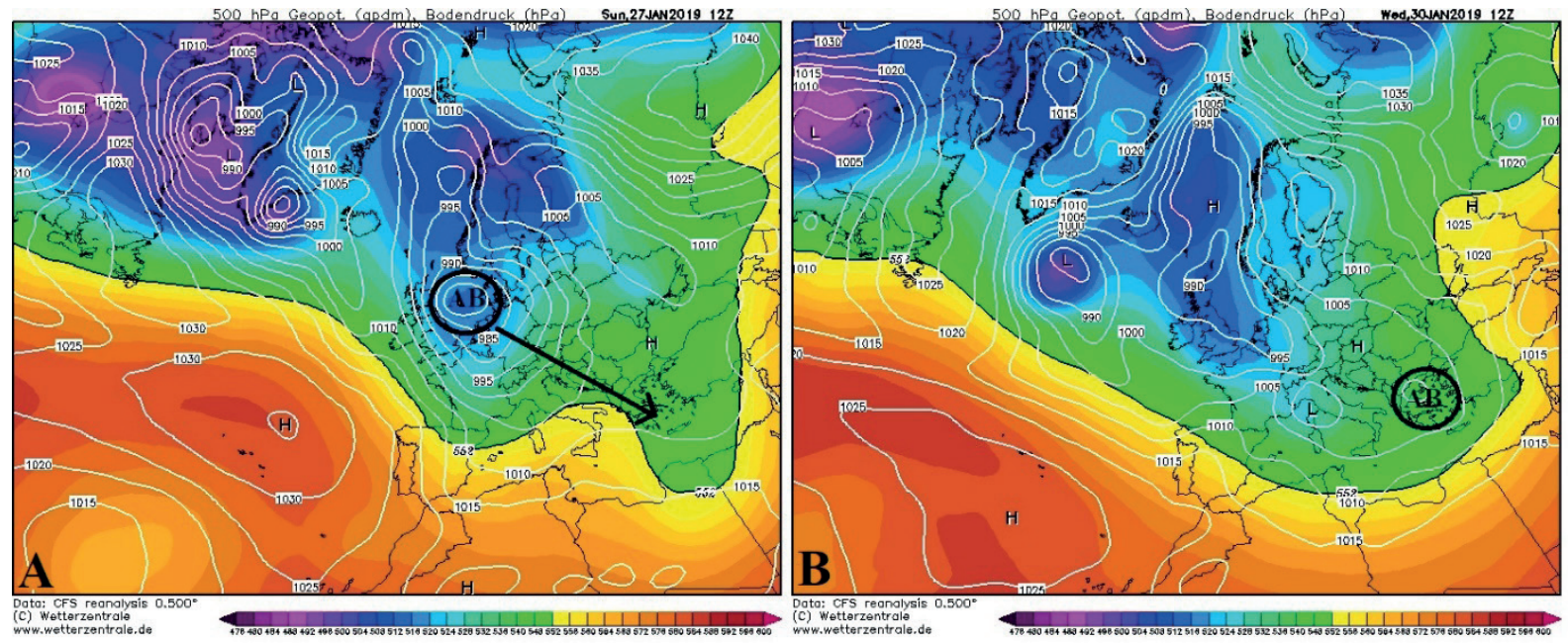

Şekil 9: Kuzey Atlantikte gelişen AB alanının sırasıyla 27 Ocak'ta Kuzeydoğu Atlantik'den (A) 30 ve 31 Ocak'ta Güney Ege ve Batı Akdeniz'e hareket doğrultusu (B) (https://www.wetterzentrale.de/reanalysis.php?map).

Figure 9: The AB area developing in North Atlantic moving from Northeastern Atlantic on January 27 (A) towards South Aegean and Western Mediterranean on January 30 and 31, respectively (B) (https://www.wetterzentrale.de/reanalysis.php?map).
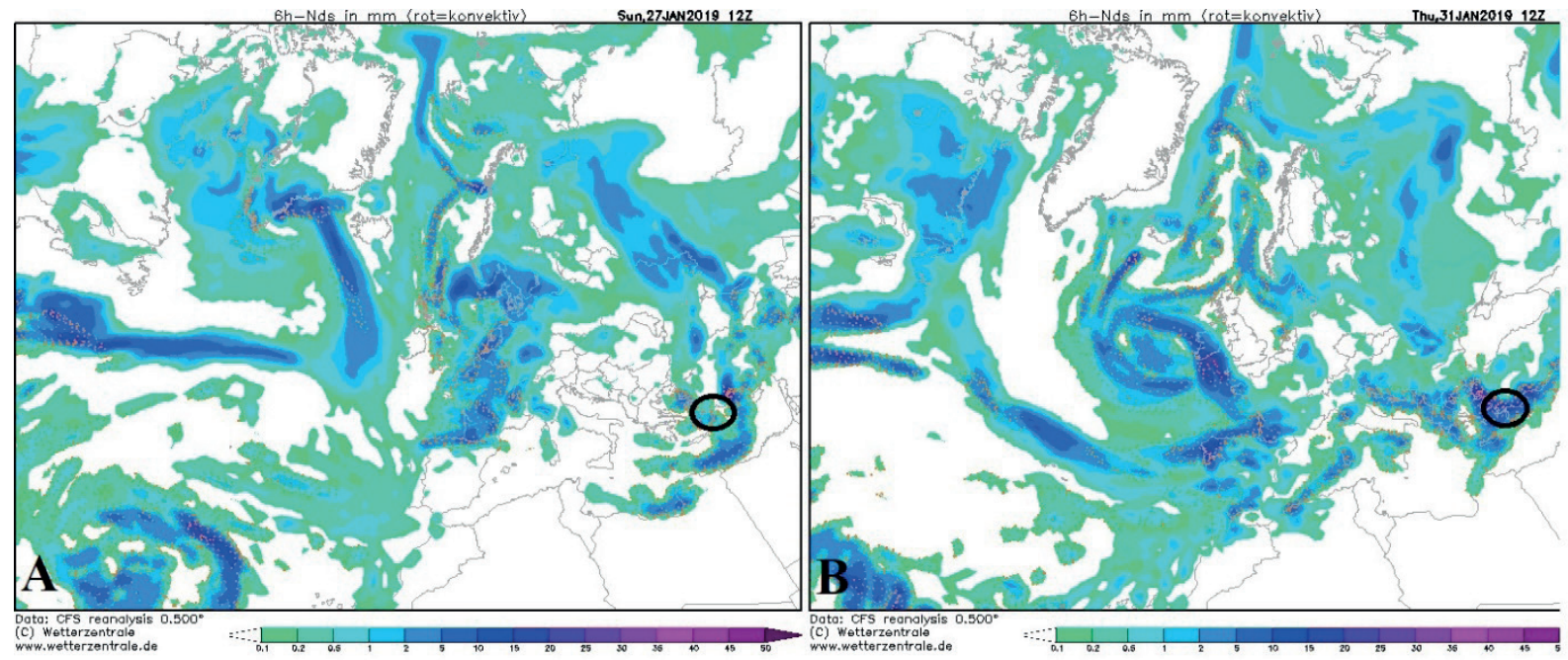

Şekil 10: Kuzey Atlantik'te gelişen ve Güney Ege kıyılarına ilerleyen AB sistemi ile beraberinde gelişen cephe hattı ve yağış'ın 27 Ocak'ta Kuzeydoğu Atlantik (A), 29 Ocak'ta Ege ve sonrasında 31 Ocak'ta Güney Ege ve Batı Akdeniz'e hareketi (B) (https://www.wetterzentrale.de/ reanalysis.php?jaar).

Figure 10: The front line and precipitation that accompanied the AB system developing in the North Atlantic and advancing to South Aegean coasts, finally moving towards Northeastern Atlantic on January 27 (A), the Aegean on January 29, and the South Aegean and Western Mediterranean on January 31 (B) (Source: https://www.wetterzentrale.de/reanalysis.php?jaar). 
Fethiye Kayaköy'de bir taşkın hadisesini ortaya çıkarmıştır. Taşkın günü ve birkaç gün önceki süreçlerin 500 hpa basınç haritalarına bakıldığında Kuzey Atlantik kökenli AB sisteminin öncelikle Kuzeybatı Avrupa, sonrasında ise Güney Ege ve Batı Akdeniz bölümüne ulaştı̆̆ görülmektedir (Şekil 9).

Güney Ege ve Batı Akdeniz'e doğru hareket eden AB sistemi ile Ege Denizi ve çalışma sahasınında içinde yer aldığı, Batı Akdeniz kıyılarında gelişen cephe hattına bağlı olarak yoğun sağanak yağışların gerçekleştĭgi, tekrardan yapılandırılmış olan modellerde ve sinoptik dağılım haritalarından da desteklenir niteliktedir (Şekil 10). Şekil 9'da görüldüğü üzere AB sisteminin Ege ve Akdeniz havzasına doğru olan hareketi temelde kita Avrupası üzerinden gerçekleştiği için basınç merkezinin mb değerinin oldukça artmış ve gücünü önemli miktarda azalttığını görebilmekteyiz. Ancak Güney Ege ve Batı Akdeniz'e ulaşan $\mathrm{AB}$ sistemi bölgede nispeten sıcak deniz suları ile etkileşime girerek nem kazandığ 1 ve gelişen cephe hattı boyunca çalışma sahası ve Güney Ege hattında kuvvetli yağışlara sebebiyet verdiği anlaşılmaktadır (Şekil 10).

Yukarıda taşkın günü ve öncesine ait olan 500 hpa haritaları ile tekrardan yapılandırılmış yağış modelleri incelenerek yorumlanmıştır. $\mathrm{Bu}$ değerlendirme sonrasında ise çalışma sahasının kuş uçuşu 6 km kuzeyinde yer alan Fethiye meteoroloji istasyonu verileri MGM (Meteoroloji Genel Müdürlüğü)'den temin edilmiş ve bölgenin günlük yağış değerleri tablolaştırılmıştır. Fethiye meteoroloji verilerine göre istasyon ve yakın çevresinde 31 Ocak Perşembe günü $87.8 \mathrm{~mm}, 1$ Şubat Cuma günü öğle saatlerinde ise 82.9 mm yağış düşmüştür (Şekil 11). Fethiye meteoroloji istasyonun dışında bölgeye nispeten yakın olan Karadă̆'ın güneyinde Muğla iline bağlı Seydikemer

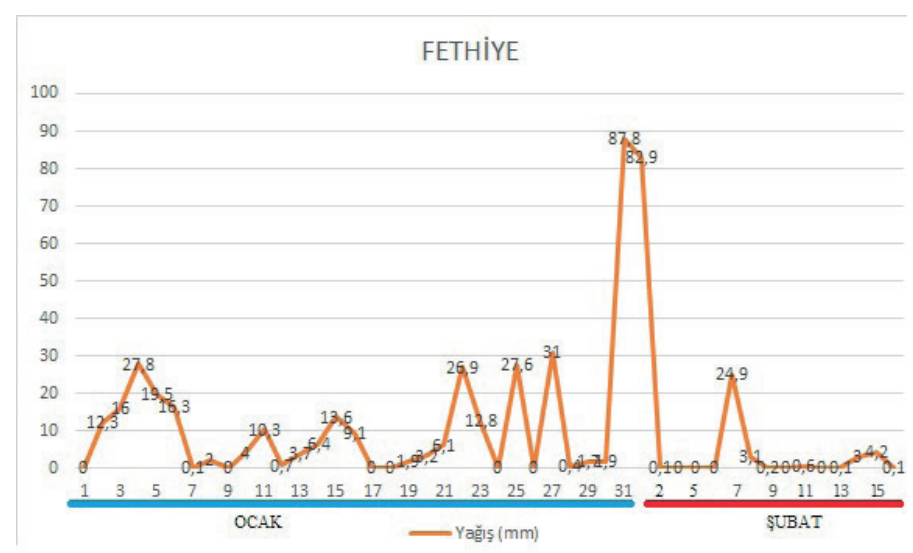

Şekil 11: Fethiye meteoroloji istasyonunda 1 Ocak -15 Şubat 2019 tarihleri arasında gerçekleşen günlük toplam yağış değerleri.

Figure 11: Total daily precipitation values between January 1 and February 15, 2019, as published by the Fethiye meteorology station. ilçe sınırları içinde yer alan ve Tübitak 117Y391 no'lu proje kapsamınca kurulmuş olan Otomatik Hava Gözlem İstasyonu (OHGI) verileride taşkın günü için incelenmiştir. İstasyondan elde edilen verilere göre 31 Ocak ve 1 Şubat günlerinde $110 \mathrm{~mm}$ üzerinde yağışın meydana geldiği tespit edilmiştir.

MGM'nin yağı̧̧ şiddeti sınıflandırmasına göre 12 saatlik zaman diliminde 76-100 mm arasındaki yağışı, şiddetli yağış olarak nitelendirmiştir (MGM, 2020). Fethiye meteoroloji istasyonu verilerine göre de 31 Ocak ve 1 Şubat 2019 günlerinde 12 saatlik aralıklarla meydana gelen yağışlarda şiddetli yağış sınıfına dahil edilebilmektedir. Özetle bu yağışların her biri kısa zaman dilimlerinde gerçekleşmiş olup Kayaköyde ortaya çıkan taşkın hadisesinin en temel sebebi olmuştur.

\subsection{Arazi Örtüsü ve Kullanımı Değişimi}

Kayaköy Polyesi Havzası geçmişten günümüze beşerî faaliyetlere sahne olmuş bir sahadır. Verimli tarım toprakları havzada tarımsal faaliyetler için elverişli şartlar oluşturmuştur. Bunun yanısıra tarihsel dönemlerde birçok medeniyeti barındırması havzada turizm faaliyetlerinin de gelişmesini sağlamıştır. Ancak geçmiş dönemlerde yalnızca tarımsal üretim için kullanılan havza tabanının günümüzde yerleşim alanlarına dönüşmesi başta taşkınlar olmak üzere ciddi mekânsal sorunlara neden olmaktadır. Uydu verilerinden elde edilen arazi örtüsü ve kullanımı haritaları analiz edildiğinde $1985^{\prime}$ den günümüze havza içerisinde yerleşim alanlarının 6 kata yakın artarak 440 hektara ulaştığı görülmektedir. Bu oran havza alanının \%10'luk bir bölümüne tekabül etmektedir (Tablo 2, Şekil 12).

1985 Genel Nüfus Sayımı'na göre havzada yer alan önemli köylerin nüfuslarına baktığımızda Hisarönü 534, Ovacık 707, Kayaköy 521 ve Keçiler'in 189 olduğu görülmektedir (Die, 1988). Aynı tarihte havzada 898,56 hektar tarım arazisi varken, 74,06 hektar yerleşim alanı bulunmaktadır (Tablo 2). 1995 yılından itibaren havzanın doğusunda yer alan Hisarönü ve Ovacık yerleşmelerinin turizm faaliyetlerine bağlı olarak mekânsal gelişim sürecine girdiği görülmektedir. Yerleşim alanlarının 119,07 hektara ulaştığı havzada tarım alanlarının 868,59 hektara gerilediği görülmektedir. Yerleşim alanlarının havza içerisindeki artışı 2005 yılında da devam etmiş ve 267,3 hektara yükselmiştir (Tablo 2).

Son yıllarda özellikle turizmin etkisiyle mekânsal gelişim süreci hızlanan havzada en dikkat çekici değişim havzanın doğusundaki Hisarönü ve Ovacık’ta olduğu görülmüştür. $\mathrm{Bu}$ yerleşmeler günümüzde idari olarak Fethiye İlçesi Ölüdeniz 


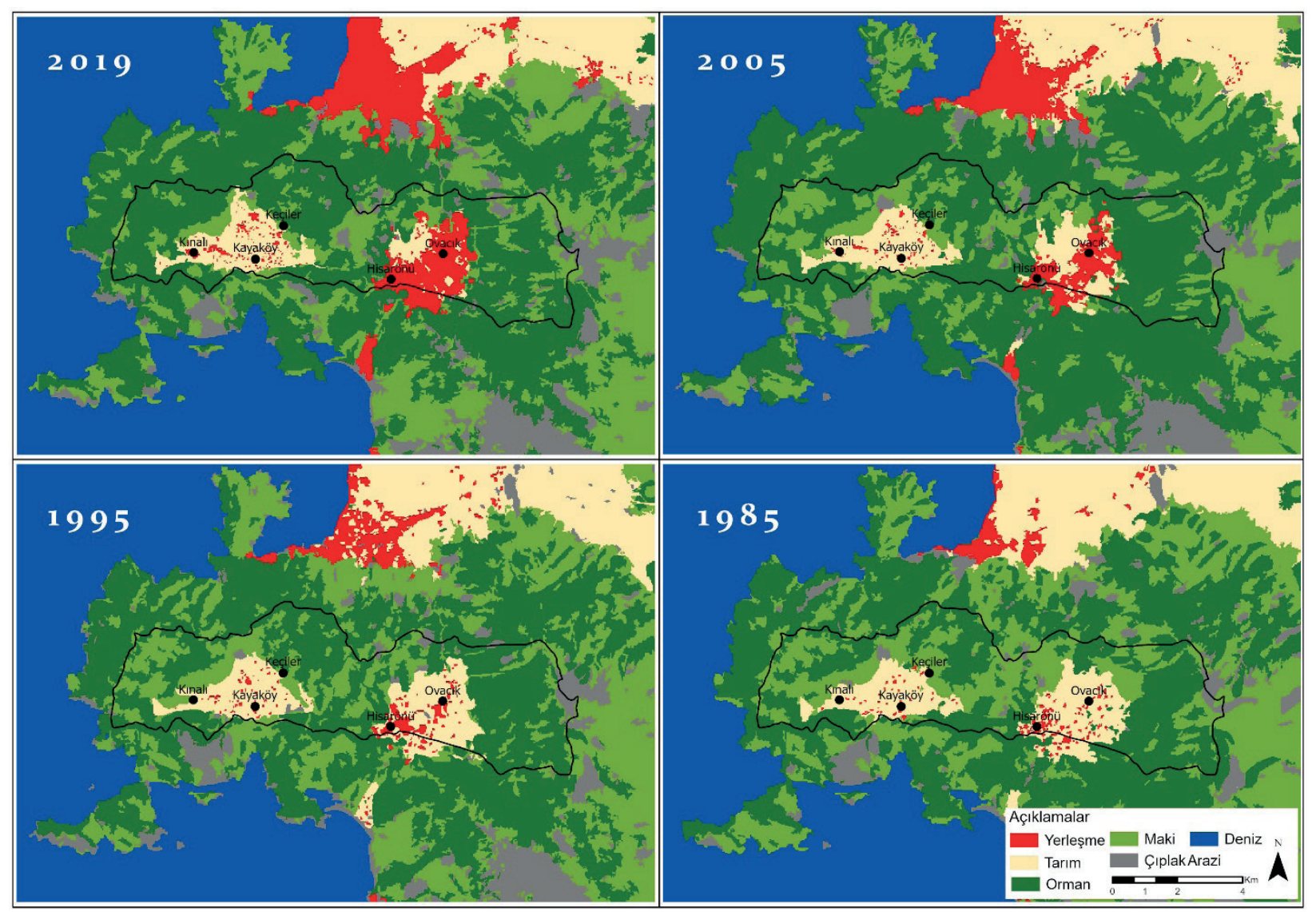

Şekil 12: Kayaköy Polyesi Havzası 1985-2019 Yılları Arazi Örtüsü ve Kullanım Durumu.

Figure 12: Land Cover and Land Use in the Kayaköy Polje Basin, 1985-2019.

Tablo 2: Kayaköy Polyesi Havzası 1985-2019 Yılları Arazi Örtüsü ve Kullanım Değişim Matrisi.

Table 2: Land Cover and Change of Land Use Matrix in the Kayaköy Polje Basin, 1985-2019.

\begin{tabular}{|c|c|c|c|c|c|c|c|c|}
\hline Sinıf & $\begin{array}{l}1985 \text { Yılı } \\
\text { (hektar) }\end{array}$ & Yüzde & $\begin{array}{l}1995 \text { Yilı } \\
\text { (hektar) }\end{array}$ & Yüzde & $\begin{array}{l}2005 \text { Yılı } \\
\text { (hektar) }\end{array}$ & Yüzde & $\begin{array}{l}2019 \text { Yılı } \\
\text { (hektar) }\end{array}$ & Yüzde \\
\hline Yerleşme & 74,06 & $1,69 \%$ & 119,07 & $2,72 \%$ & 267,3 & $6,10 \%$ & 440,19 & $10,04 \%$ \\
\hline Tarımsal Arazi & 898,56 & $20,49 \%$ & 868,59 & $19,81 \%$ & 755,91 & $17,24 \%$ & 606,15 & $13,82 \%$ \\
\hline Orman & 1921,23 & $43,81 \%$ & 2164,05 & $49,35 \%$ & 2179,26 & $49,70 \%$ & 2297,7 & $52,40 \%$ \\
\hline Seyrek Orman & 1416,15 & $32,30 \%$ & 1131,12 & $25,80 \%$ & 1079,64 & $24,62 \%$ & 898,11 & $20,48 \%$ \\
\hline Çıplak Arazi & 74,88 & $1,71 \%$ & 102,06 & $2,33 \%$ & 102,78 & $2,34 \%$ & 142,74 & $3,26 \%$ \\
\hline Toplam & 4384,88 & $100,00 \%$ & 4384,89 & $100,00 \%$ & 4384,89 & $100,00 \%$ & 4384,89 & $100,00 \%$ \\
\hline
\end{tabular}

Mahallesine bağlı birer semt haline gelmişlerdir. 5807 kişinin yaşadığı bu yerleşim alanları Ölüdeniz havzanın doğusunda yer alan ova tabanının neredeyse tamamına yayılmış durumdadır. Havzanın batısında yer alan Kayaköy'de benzer bir hızlı değişim yaşanmasa da 2019 yılı arazi örtüsü ve kullanımı haritaları incelendiğinde polye tabanında yerleşim alanlarının artış gösterdiği görülmektedir (Şekil 12).

$\mathrm{Bu}$ durum havzada meydana gelen su taşkınlarında zarar görebilirliğin artmasına neden olmaktadır. Havzanın batısındaki
Kayaköy ve çevresindeki artışın doğudaki Ölüdeniz (Hisarönü ve Ovacık) yerleşik alanına göre daha az olmasının en temel nedeni ise sahanın büyük bir bölümünün Kayaköy Kentsel Sit Alanı, I. ve III. Derece Arkeolojik Sit Alanları içerisinde kalmasından kaynaklanmaktadır (Şekil 13). Kayaköy Polyesi Havzası'nın günümüz arazi örtüsü ve kullanım durumu incelendiğinde ise son 34 yılda yerleşim alanlarının 440,19 hektara ulaştı̆̆ buna karşılık tarım alanlarının 606,15 hektara gerilediği yapılan analizlerden anlaşılmaktadır (Tablo 2, Şekil 14). 


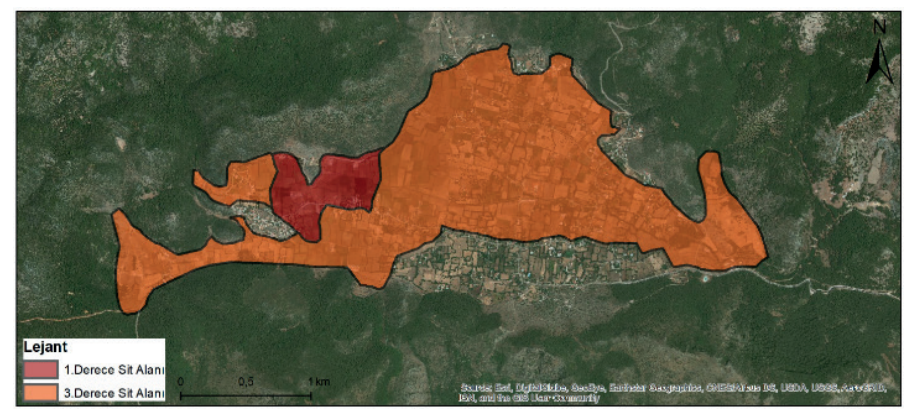

Şekil 13: Kayaköy Kentsel Sit Alanı, I. ve III. Derece Arkeolojik Sit Alanları.

Figure 13: Kayaköy Urban Protected Area, Archeological Site of Class I and III.

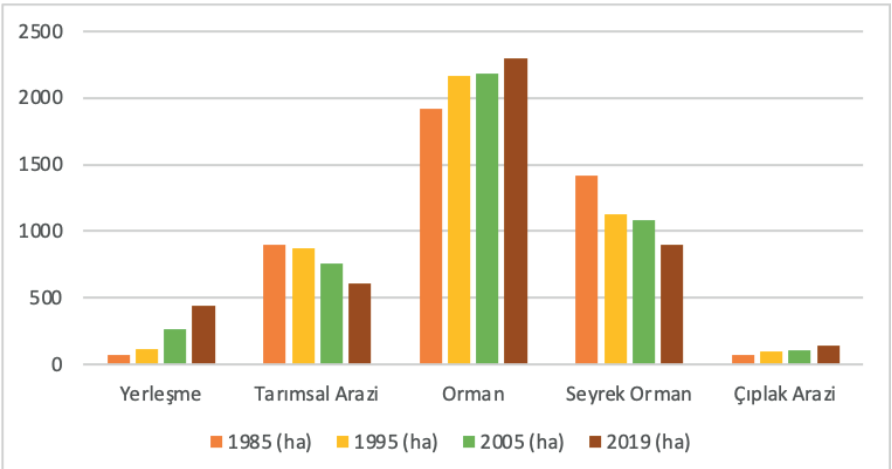

Şekil 14: Çalışma Sahası Arazi Örtüsü ve Kullanım Durumu Yıllara Göre Karşılaştırması.

Figure 14: Comparative Analysis of Land Cover and Land Use Over the Years.

\section{TARTIŞMA}

Taşkının oluşumunda; havzada kısa sürede gelişen kuvvetli sağanak yağışlar, havzanın büyüklüğü, jeomorfolojik yapısı, eğimi, bitki örtüsü yoğunluğu, toprak yapısı ve yağış akış dengesi çok önemlidir. Taşkınların etkilerini artıran unsurlar ise; iklim değişikliği, akarsu havzalarında yaşanan değişiklikler, taşkın yataklarına olumsuz müdahaleler, taşkın riski taşıyan alanlarda ve havzalarında plansız kentleşme, yetersiz boyutlarda tasarlanan mühendislik yapıları olarak gösterilebilir.

31 Ocak 2019 Kayaköy Polyesi Taşkını'nın oluşumdaki en önemli faktörlerden biri taşkın günü kısa sürede gelişen kuvvetli sağanak yağışlar olsa da taşkın öncesi dönemde süregelen yağışların da etkisi vardır. Ocak ayının ilk günlerinden itibaren Fethiye ve yakın çevresinde etkili olan cephe sistemlerinin ortaya çıkardığı yağışlı periyotlar sonucunda taşkın gününe kadar bölgeye bir ayda yaklaşık 255,3 mm civarı yağış düştüğü saptanmıştır (Şekil 11). Bu durum ise halihazırda bölgede taşkın öncesinde polye tabanında yeraltı suyu seviyesinin yükselmesine, havza genelinde toprağın suya doymasına ve Kayaköy Polyesi'nde yer alan düdenlerin yağışlarla gelen malzemeler tarafından tıkanmaya başlamasına neden olmuştur. Bundan dolayı taşkın öncesi Ocak ayı içerisinde kısa aralıklarla devam eden yağışlar taşkın günü düşen kuvvetli sağanak yağışların afet boyutuna dönüşmesinde oldukça etkili olmuştur (Şekil 15).

Kayaköy Polyesi Taşkını'nın oluşumdaki diğer önemli bir faktör ise Kayaköy Polyesi Havzası'nın morfometrik
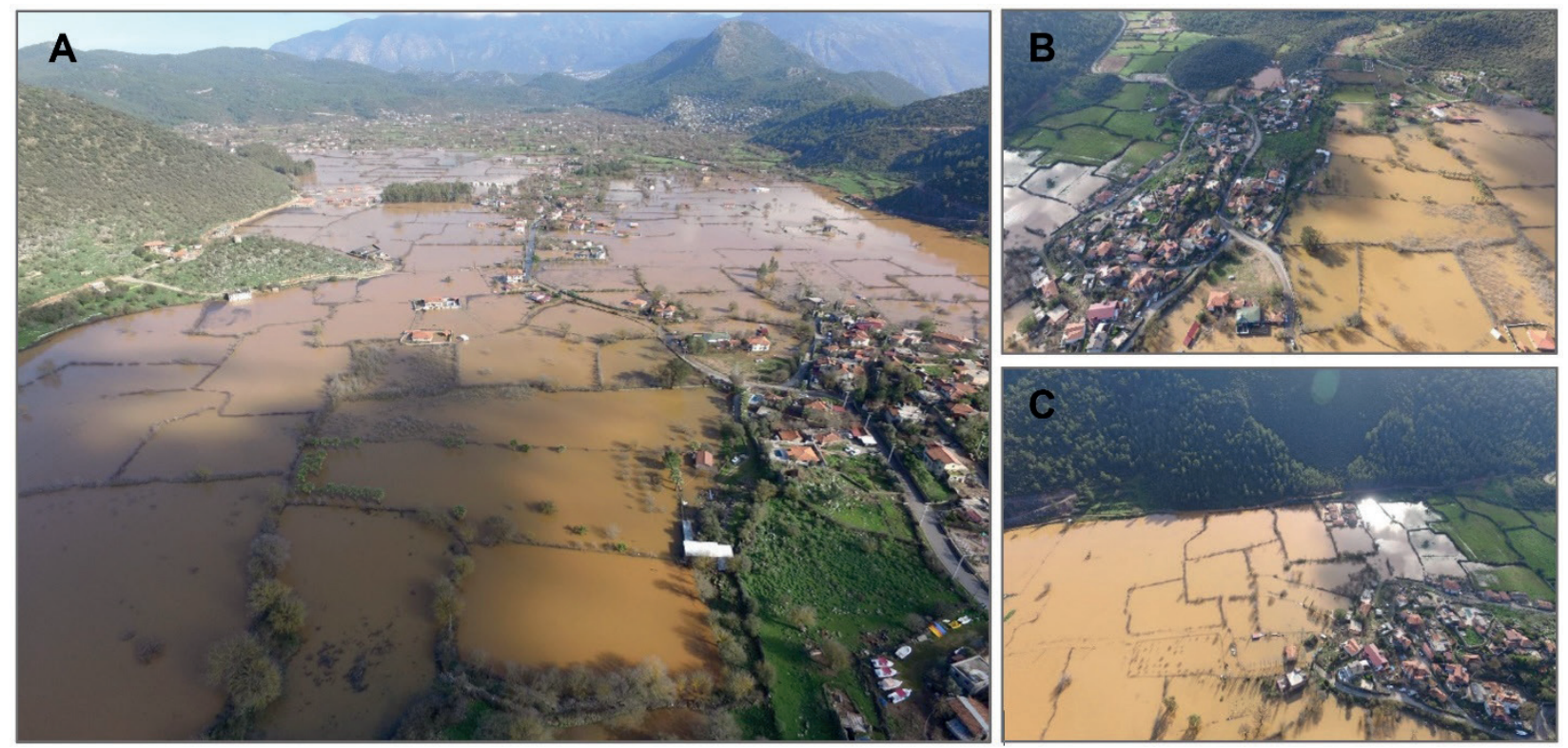

Şekil 15: Taşkın sırasında Kayaköy Polyesi'nin alçak noktasında yer alan Kınalı mahallesine batıdan (A), doğudan (B) ve kuzeyden (C) bakış. Figure 15: View of the Kınalı neighborhood during the flood from west (A), east (B), and north (C). Kınalı is located at a low point of the Kayaköy Polje. 


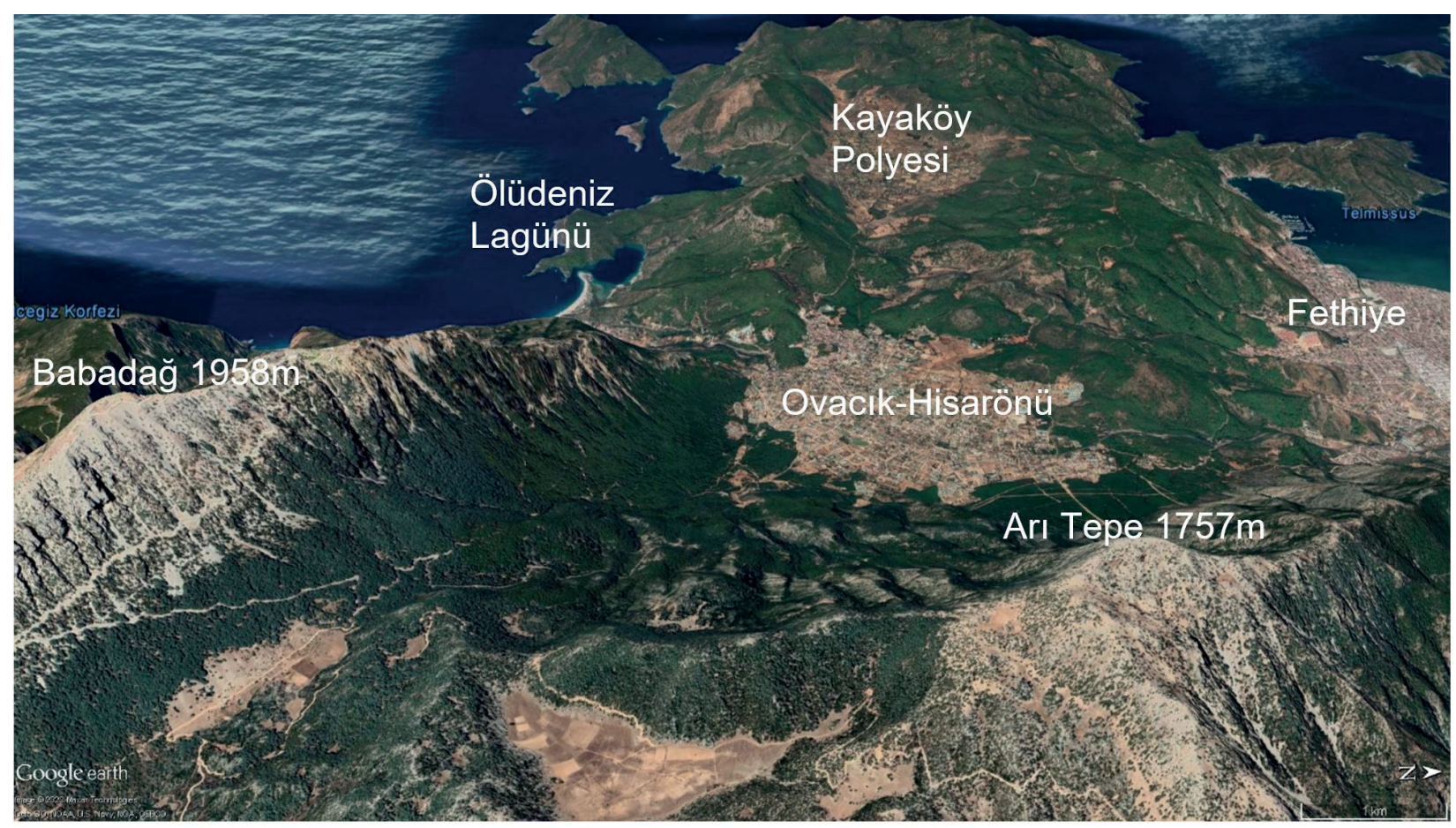

Şekil 16: Doğudaki yüksek kütlelerden batı yönündeki Kayaköy Polyesi'nin Google Earth görünümü.

Figure 16: Google Earth view of the Kayakoy Polje basin from the elevated mass on the east in the direction of west.

özellikleridir. Kayaköy Polyesi Havzası büyük taşkınlar yaratan havzalara kıyasla göreceli olarak küçük bir havzaya $\left(43 \mathrm{~km}^{2}\right)$ sahiptir. Fakat havzanın doğu sınırındaki yüksek kısımlardan (1757 m) havza tabanına (140 m) kuş uçuşu 11 km gibi kısa bir mesafede ulaşılması aşırı ve ani yağışların olduğu dönemlerde havzaya düşen yağışın hızlı bir şekilde depresyon tabanında birikmesine neden olmaktadır (Şekil 16). Oldukça hızlı hareket eden bu su kütlesinin düdenlerle dış drenaja aynı hızda aktarılamaması taşkınları kaçınılmaz hale getirmektedir.

Yine havza içerisindeki yapılaşmalar hem doğal infiltrasyon (sızma) ve hem de doğal eğim koşullarının değişmesine neden olmaktadırlar (Turoğlu, 2011). Kayaköy Polyesi Havzası doğusunda Ovacık yerleşmesinin üzerinde kurulduğu birikinti konisi ve yelpazesi son yıllarda artan hızlı yapılaşma nedeniyle beton ve asfaltla kaplanmıştır. Buna bağlı olarak 31 Ocak ve 1 Şubat 2019 tarihlerinde Babadağ' 1 batı yamacına düşen aşırı yağışlar $(170 \mathrm{~mm})$ ile yüzeysel akışa geçen su asfalt ve beton zeminden dolayı infiltrasyon ile azalmamış ve Kayaköy Polyesi'ne hızlıca yönelmiştir. Kayaköy Polyesi'ne yönelen bu hızlı akışı azalmak için Kirişli ve Nergizli Tepe arasındaki boğazda küçük bir set yapılmış ama zamanla bu settin gerisi günümüzde tamamen alüvyonla dolmuş ve set işlevini yitirmiş̧ir (Şekil 17).

Kayaköy Polyesi aşırı yağışlar ve yapılaşma dışında polyeyi drene eden düdenler üzerindeki insan mudahaleleri de taşkının oluşmasındaki diğer bir faktördür. Kayaköy Polyesi tabanı Kayaköy Kentsel Sit Alanı, I. ve III. Derece Arkeolojik Sit Alanları içerisinde kalmasından dolayı yoğun bir yerleşime sahip olmasa da birkaç düden, evler, tarım alanları ve yollar tarafından ya kapatılmış ya da suların düdene yönelmesine engel olacak şekilde konumlandırılmıştır. Yine Kayaköy Polyesi tabanındaki en faal düdenlerden biri daha önceleri taş örgülü bir duvara sahipken sonradan beton bir kuyuya dönüştürülmüştür. Taş örgülü kuyu/düden polye tabanındaki yeraltı suyu taş örgü arasından sızdırarak yeraltına kanalize ederken, beton kuyu sadece ağız kısmından suyu aldığı için yer altı su seviyesini yükseltmekte ve kısa süre aralığında gerçekleşen aşırı yağışlarda zaten yeraltı su seviyesi yükselmiş polye tabanında taşkın oluşmasını kaçınılmaz hale getirmektedir. Ayrıca polye tabanında düdenlere su akışını hızlandıran kanallar ve düdenlerin ağız kısmı düzenli olarak temizlenmediği için polye tabanında biriken suyun drene edilmesi zorlaşmaktadır (Şekil 18).

Polyelerde oluşan taşkınlar diğer jeomorfolojik birimlerde oluşan taşkınlardan farklılık göstermektedir. Geniş tabanlı akarsu vadilerinde oluşan taşkınların etkisi birkaç gün ile sınırlı kalırken Polye taşkınlarında bu süre ayları bulabilmektedir. Bu da başta tarım alanları olmak üzere yerleşim alanlarının, yolların, orman veya meraların aylarca sular altında kalması demektir. Akarsu vadilerindeki taşkının zararlarına birkaç gün içinde çözüm bulunmaya başlanırken polye taşkınlarında suyun 

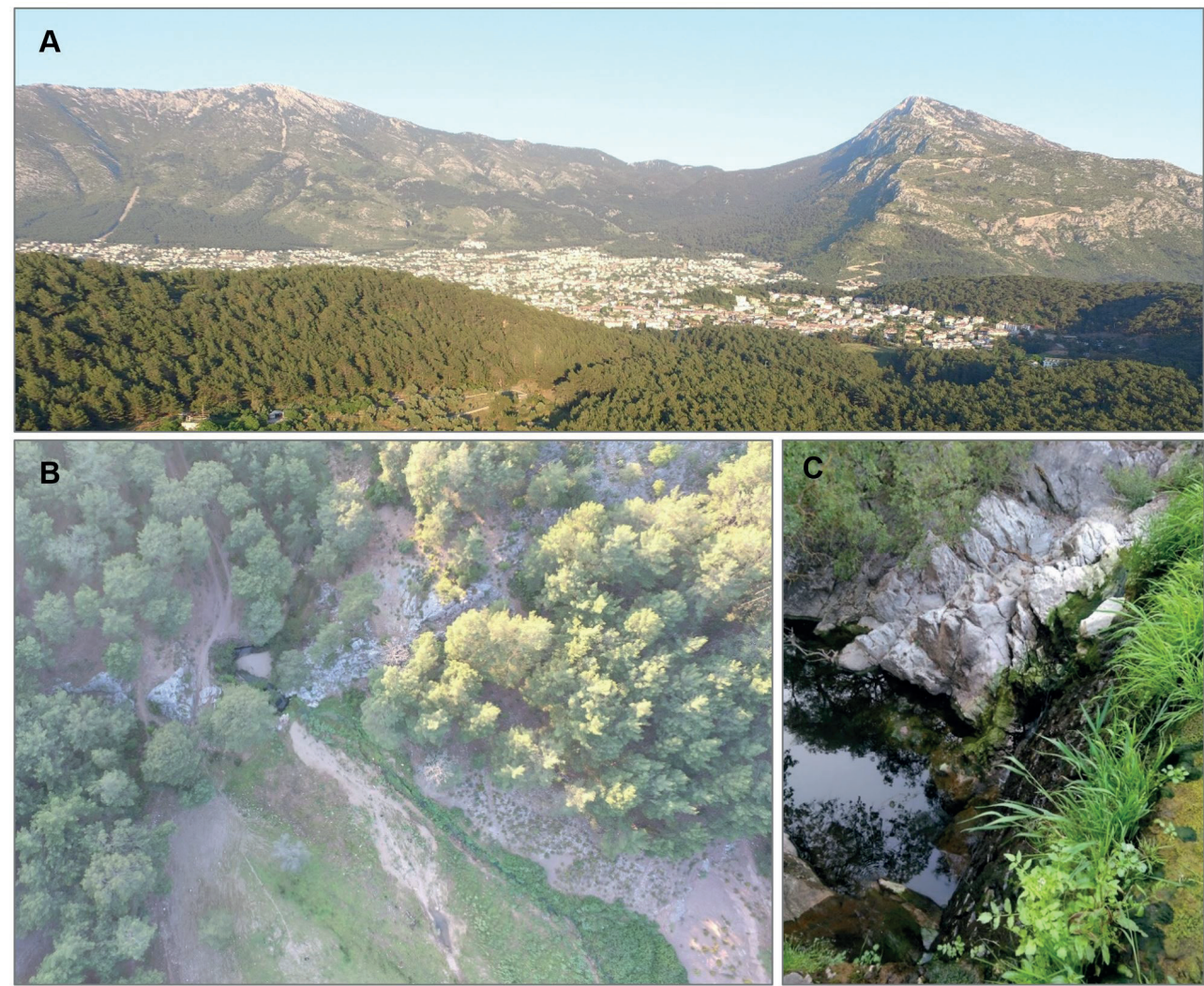

Şekil 17: Ovacık-Hisarönü yerleşimine batıdan bakış (A)ve Hisarönü Kayaköy arasındaki birleştirme boğazındaki alüvyonlarla dolmuş taşkın setti (B, C). Figure 17: View of the Ovacık-Hisarönü settlement (A) from the west and the alluvial-filled flood embankment in the gorge between Hisarönü (B) and Kayaköy (C).

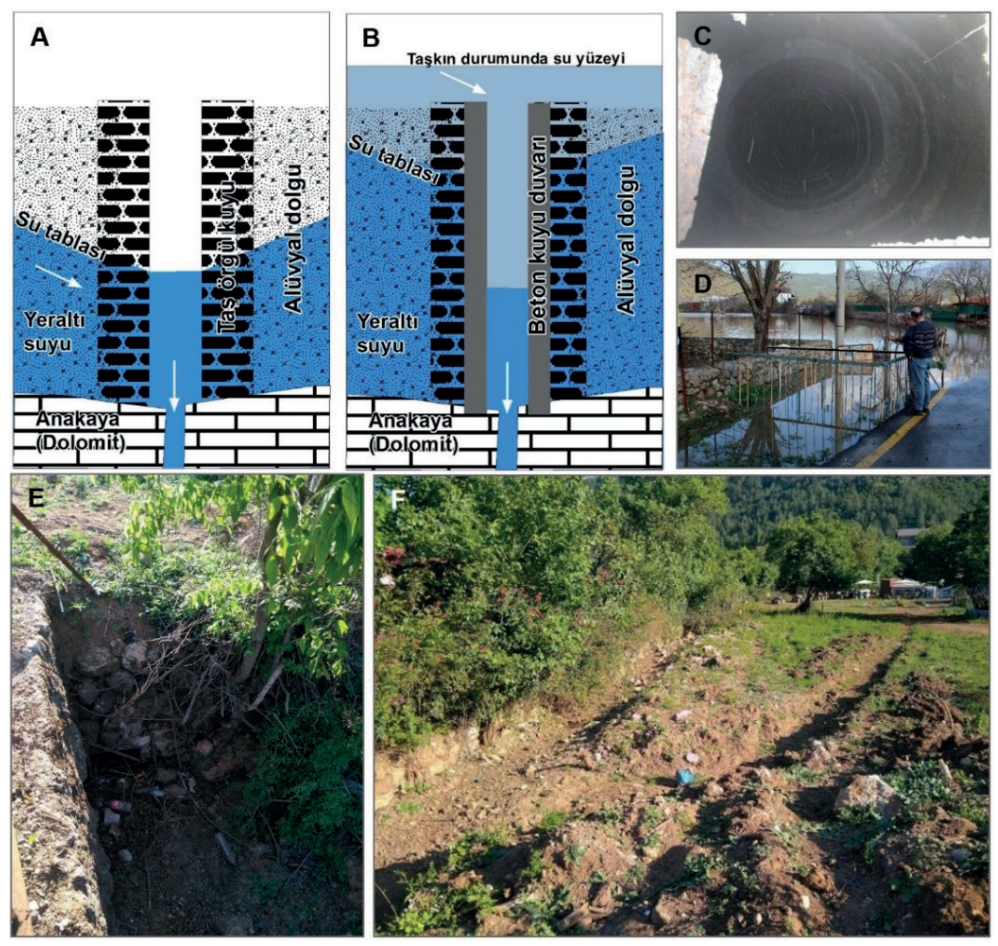

Şekil 18: Kayaköy Polyesi tabanındaki eski düdenin taş örgülü kuyu hali (A), betonla kaplanmış hali (B, C) ve aynı düdenin taşkın sırasındaki durumu (D) ve taşkın sonrasında kısmen tıkanmış düden girişi (E) ve düdene yönelen tarla içindeki basit kanallar (F).

Figure 18: The old ponor in the Kayaköy Polje turned to a well covered with stone masonry $(A)$, sealed with concrete $(B, C)$, its status during the flood $(D)$, its partially blocked entrance in the aftermath of the flood $(E)$ and simple canals in the field leading to the ponor (F). 
çekilmesi için çok uzun süre beklenilmesi gerekmekte bu da zararın boyutunu kat ve kat arttırmaktadır.

Kayaköy Polyesi'nde 31 Ocak 2019 tarihinde oluşan taşkınla su altında kalan alanlarda hayatın ve ekonomik aktivitenin normele dönmesi Nisan 2019 sonunu bulmuştur. 2019 yılının Temmuz ayında yapılan arazi çalışması sırasındaki mülakatlar ve uydu görüntülerinden elde edilen veriler ile bu durum net bir şekilde ortaya konabilmiştir (Şekil 19).

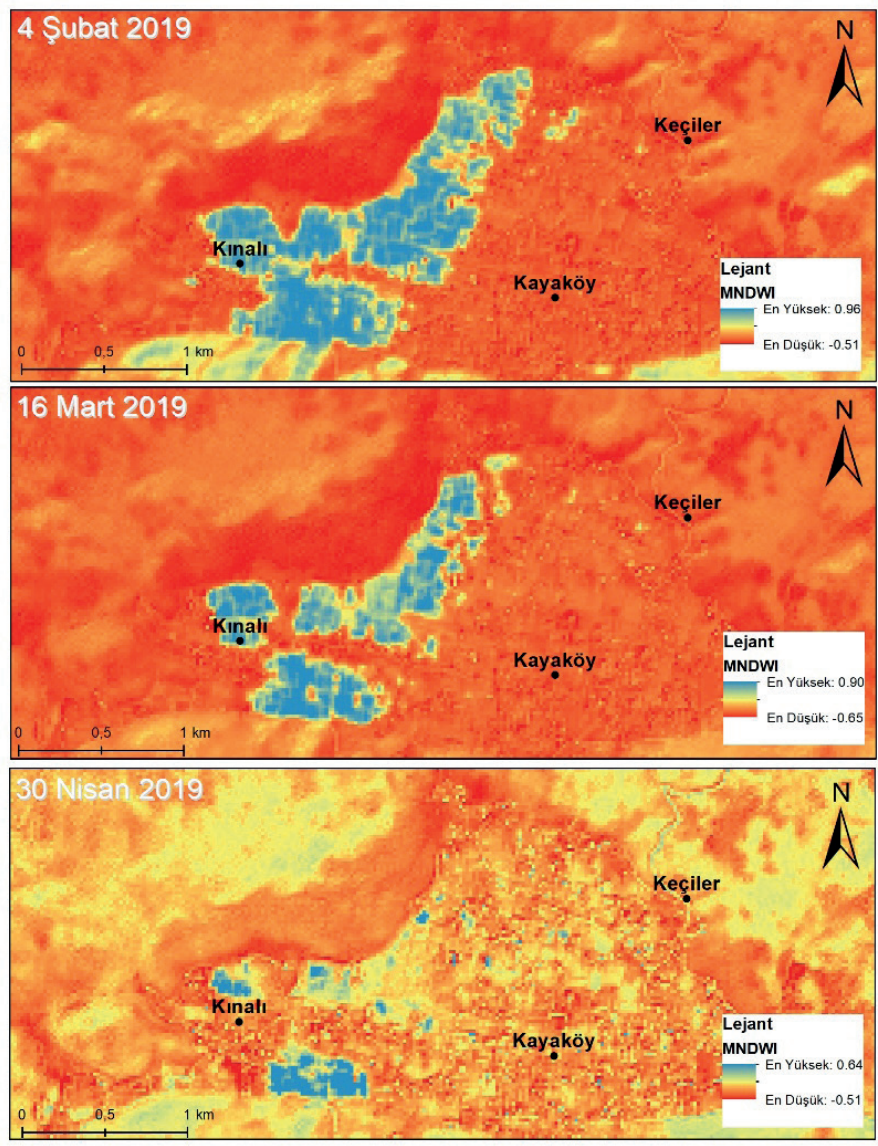

Şekil 19: Sentiel-2 uydu verisininden elde edilen MNDWI analizleri sonucunda Kayaköy Polyesi Taşkını́nın 4 Şubat, 16 Mart ve 30 Nisan 2019 tarihlerindeki yayılış alanları (taşkın alanları mavi renkle görünmektedir).

Figure 19: MNDWI analysis obtained from Sentiel-2 satellite data showing the distribution of Kayaköy Polje floods on February 4, March 16 and April 30, 2019 (flood areas appear in blue).

\section{5. ÖNERÍLER}

İklim değişimine bağlı olarak yükselen sıcaklık değerleri hem taşkınların hem de kuraklık riskinin artmasına neden olmaktadır (Wetherald ve Manabe, 2002; IPCC, 2007). Sıcaklıklardaki artışlar yılın bütün mevsimleri için sözkonusu iken, yağışlar ise bir mevsim artarken diğer mevsimde azalabilmektedir. Bazı güçlü bulgulara göre de yağışlardaki bu değişkenlik gelecekte daha da artacaktır (Trenberth, Dai, Rasmussen ve Parsons, 2003). Bu da yağışların yıl içindeki süreksizliğine ve dolayısıyla ani ve sağanak yağışların artmasına neden olacaktır. Bu durumun ortaya çıkaracağı en doğal sonuç, birçok havzada taşkınların meydana gelmesidir (Özdemir, 2011). Kayaköy Polyesi de sahip olduğu fiziki coğrafya şartları nedeniyle bu tür taşkınlardan en fazla etkilenecek alanların başında gelmektedir. Özellikle yüzeysel bir drenaja sahip olmaması ve su toplama havzasında çok fazla beşerî müdahalenin bulunması Kayaköy Polyesi'ne daha fazla risk altında bırakmaktadır. Bu risk faktörleri göz önüne alındığında zarar azaltıcı ne tür önlemler alınabilirliği konusunda öneriler aşağıdaki gibi sıralanabilir;

- Kayaköy Havzası'nın doğu kısmını oluşturan OvacıkHisarönü yerleşmelerinin olduğu kısımda yoğun betonlaşma neticesinde zemine sızamayan suyu kanallarla batıdaki Kayaköy Polyesi yerine $15 \mathrm{~m}$ bir eşikle ayrılan Ölüdeniz mevkiinde denize aktarılabilir.

- Havzanın doğusu ile batısı arasındaki boğazda yer alan ve alüvyonla dolan settin yerine daha büyük boyutta bir taşkın önleme barajı yapılabilir.

- Kayaköy Polyesi tabanında mevcut düdenlerinde bulunduğu fay hatları üzerinde detaylı jeofizik ölçümler yapılarak tespit edilecek yeraltı çatlak ve boşluklara sondaj yapılmak suretiyle düden görevi görecek yeni su kaçış alanları oluşturulabilir.

- Üzerleri kapatılmış eski düdenler aktif hale getirebilir ve mevcut düdenlerin tıkanmasını önleyecek önlemler alınabilir.

- Maliyetli bir yatırım olsa da polye tabanında (140 m) biriken sular çanağının güneybatısında yer alan en alçak eşikten (175 m) motopompalar ile drene edilebilir.

Yukarıda belirtilen önerilerin uygulanabilirliği kanun, yönetmelik ve genelgelerle belirlenmiş̧ir. Bu bahiste, taşkınla ilişkili 25 adet kanun, 8 adet yönetmelik, 4 adet genelge, 1 adet tebliğ yer almaktadır. Taşkınla doğrudan ilgili olan 1943 yılında çıkarılan 4373 sayılı Kanunla taşkına uğrayan ve uğraması muhtemel sahaların tespiti ve bu sahaların iskana kapatılarak taşkına neden olacak yapılar var ise kaldırılması konusu hükme bağlanmıştır (Resmî Gazete (RG), 2020). 1953 y1lında ise 6200 sayılı Kanunla DSİ'nin birinci sıradaki görevi "taşkın sular ve sellere karş1 koruyucu tesisler meydana getirmek" olarak belirlenmiştir (RG, 2020). Yine 2004 yılında çıkarılan 5216 sayılı kanun ile Sayılı Büyükşehir Belediyesi Kanunu'nda "derelerin ıslahını yapmak" ifadesi ile belediyelere bu konuda 
görev verilmiştir (RG, 2020). Ayrıca 2006 tarih ve 26284 sayılı "Dere yatakları ve Taşkınlar" ve 2010 tarih ve 27499 sayılı "Akarsu ve Dere Yatakları Islahı" ile ilgili Başbakanlık genelgeleri ile tüm taşkın zararlarının asgariye indirilebilmesi için ilgili kurum ve kuruluşların yerine getirmesi gereken hususlar belirtilmiştir (RG, 2020). Bilim insanlarının bu noktada görevi taşkına uğrayan ve uğraması muhtemel sahaların tespiti konusunda kamu kurum ve kuruluşların bilgilendirmek olduğu gibi taşkınlarla oluşan zararların en aza indirgenmesi konusunda önerilerde bulunmak olmalıdır. Ayrıca bilim insanlarının taşkın konusundaki mevzuat hükümlerinin güncellenmesi konusunda da destek vermeleri gerekmektedir.

\section{SONUÇLAR}

Kayaköy Polyesi Fethiye'nin $6 \mathrm{~km}$ güneyinde deniz seviyesinden 140 m yükseklikte, $5 \mathrm{~km}$ uzunluğunda, $2 \mathrm{~km}$ eninde ve $5 \mathrm{~km}^{2}$ alana sahip dolomitler içinde oluşmuş dış drenaja kapalı tipik bir karstik depresyondur. Kayaköy Polyesi su toplama havzası ise $43 \mathrm{~km}^{2}$ alan kaplayıp doğuda yer alan Ovacık-Hisarönü ovalarını da kapsar ve havzanın suları polyenin batısında iki düden ile dış drenaja bağlanır. 27 Ocak 2019 tarihi itibari ile gelişmeye başlayan Kuzey Atlantik Kökenli AB sistemi zamanla Akdeniz Havzasına doğru hareket ederken sıcak deniz suları ile etkileşime girerek nem kazanmış ve 31.01.2019 ile 01.02.2019 tarihleri arasında Güney Ege hattında kuvvetli yağışlar meydana gelmesine neden olmuştur. Kuvvetli yağışlar öncesinde gerçekleşen yağışlarla suya doygun hale zemin Fethiye ve yakın çevresinde etkili olan aşırı yağışlar $(170 \mathrm{~mm})$ ile bölgede küçük ölçekli sel ve taşkınlara sebep olsa da afet boyutuna ulaşacak en büyük etkiyi Kayaköy Polyesi'nde yarattığı taşkın ile göstermiştir. Hidrometeorolojik kökenli doğal afetlerden olan bu taşkının oluşmasında kısa sürede gelişen kuvvetli sağanak yağışların yanında havzadaki hızlı yapılaşma sonucunda doğal sızma ve eğim koşullarının değişmesi, taşkın koruma yapılarının işlevini yitirmesi, düdenlerin tıkanması ya da beton kuyulara dönüştürülmesi etkili olmuştur. Polye taşkınlarında suyun çekilmesi için çok uzun süre beklenilmesi gerekmekte bu da zararın boyutunu kat ve kat arttırmaktadır. Kayaköy Polyesi'nde 31 Ocak 2019 tarihinde oluşan taşkınla su altında kalan alanlarda hayatın ve ekonomik aktivitenin normale dönmesi Nisan 2019 sonunu bulmuştur.

Kayaköy Polyesi yüzeysel bir drenaja sahip olmaması ve su toplama havzasında çok fazla beşerî müdahalenin bulunması nedeniyle fazlaca taşkın riski altında bir alandır. Bu risk faktörleri göz önüne alındığında havza ıslahı ve taşkın önleme yapıları yapılacağı gibi mevcut düdenlerin aktif tutup jeofizik yöntemlerle uygun yeraltı çatlak ve boşlukları tespit edilerek buralara yapılacak sondajlarla yeni su kaçış alanları oluşturulabilir. Yine taşkın döneminde polye tabanında biriken sular alçak eşiklerden motopompalar ile drene edilebilir. Tüm bu öneriler taşkınlara karşı önlem alma ve olası afet durumunda taşkın alanlarının 1slahı konusunda kanunla yetkilendirilmiş kamu kurum ve kuruluşlarla koordineli bir şekilde değerlendirilmelidir.

Aslında 1900'lü yılların başına kadar yerleşime açık olan Kayaköy Örenyeri bize tarihsel deneyimlerin yerleşmin alanlarının polye tabanına değilde yamaçlara kurulması gerektiğini açıkca göstermiştir. Fakat mübadele sonrası yerleşim yerlerinin eskisi gibi yamaçlara değilde polye tabanına yayılması ve bunun o dönem yetersiz olan yasal düzenlemelerle engellenememesi günümüzdeki afetleri kaçınılmaz hale getirmiştir. Bu nedenle her türlü doğal afet önleme çalışmalarında tarihsel deneyimleri göz önünde bulundurmak belki de en mantıklı ve ekonomik çözüm yolu olacaktır.

Katkı Belirtme: Bu çalışmada TÜBİTAK ÇAYDAG 117 Y391 nolu projesi kapsamında kurulan Söğütlüdere meteroloji istasyonu verilerinden faydalanılmıştır. Yazarlar meteoroloji verisi ve arazi çalışması çalışması konusundaki destekten dolayı TÜBİTAK'a teşekkürü bir borç bilirler.

Hakem Değerlendirmesi: Dış bağımsız.

Çıkar Çatışması: Yazarlar çıkar çatışması bildirmemiştir.

Finansal Destek: Yazarlar bu çalışma için finansal destek almadığını beyan etmiştir.

Peer-review: Externally peer-reviewed.

Conflict of Interest: The authors have no conflict of interest to declare.

Grant Support: The authors declared that this study has received no financial support.

\section{KAYNAKÇA/REFERENCES}

Akarsu ve Dere Yataklarının Islahı. (2010, 20 Şubat). Resmi Gazete (Sayı: 27499). Erişim Adresi: https://www.resmigazete.gov.tr/ eskiler/2010/02/20100220-17.htm

Akşit, O. (1967). Likya tarihi. İstanbul: İ.Ü Edebiyat Fak. Yayını:1218. Avşarcan, B. (1992). Fethiye körfezi ve çevresinin jeomorfolojisi. İstanbul: Deniz Bilimleri ve İşletmeciliği Enstitüsü, Basılmamış Doktora Tezi.

Bahadır, M. (2014). Samsun'da meydana gelen 4 Temmuz ve 6 Ağustos 2012 taşkınlarının klimatik analizi. Coğrafya Dergisi, (29), 28-50.

Bonacci, O. (2013). Poljes, Ponors and Their Catchments. In: John F. Shroder (Editor-in-chief), Frumkin, A. (Volume Editor). Treatise on Geomorphology, Vol 6, Karst Geomorphology, San Diego: Academic Press; 2013. (112-120). DOI: 10.1016/B978-0-12-374739-6.00103-2

Banko, G. (1998). “A Review of Assessing the Accuracy of Classifications of Remotely Sensed Data and of Methods Including Remote Sensing Data in Forest Inventory. Working Papers ir98081, International Institute for Applied Systems Analysis. 
Bilici, Ö., \& Everest, A. (2017). 29 Aralık 2016 Mersin selinin meteorolojik analizi ve iklim değişikliği bağlantısı. Doğu Coğfraya Dergisi, (9), 246-260.

Biricik, A. S., Bozyiğit, R., \& Kurt, H. (1998). Kayaköy polyesi ve yakın çevresinin jeomorfolojisi (Fethiye-Muğla). Marmara Coğrafya Dergisi, 2, 150-173.

Bozcu, M., Yağmurlu, F., \& Şentürk, M. (2007). Fethiye-Burdur fay zonunun bazı neotektonik ve paleosismolojik özellikleri, GBTürkiye. Jeoloji Mühendisliği Dergisi, 31(1), 25-48.

Buldur, A., Pınar, A., \& Başaran, A. (2007). 05-07 Mart 2004 Tarihli Göksu nehri taşkını ve Silifke'ye etkisi. Selçuk Üniversitesi Sosyal Bilimler Enstitüsü Dergisi, (17), 139-160.

Cheyette, F. L. (2014). The mediterranean climate. John Wiley \& Sons, Ltd.

Congalton, R., \& Green, K. (2009). Assessing the accuracy of remotely sensed data principles and practices. Boca Raton: CRC Press Taylor\&Francis Group.

Dere Yatakları ve Taşkınlar. (2006, 9 Eylül). Resmî Gazete (Sayı: 26284). Erişim Adresi: https://www.resmigazete.gov.tr/eskiler/2006 /09/20060909-3.htm

Devlet Su İşleri Umum Müdürlüğü Teşkilât ve Vazifeleri Hakkında Kanun. (1953, 25 Aralık). Resmi Gazete (Sayı: 8592). Erişim Adresi:https:/www.resmigazete.gov.tr/arsiv/8592.pdf

Die. (1988). Genel nüfus sayımı, 20.10.1985: Nüfusun sosyal ve ekonomik nitelikleri: Muğla. Ankara: Başbakanlık Devlet İstatistik Enstitüsü.

Doğan, U. (1996). Polye ve Fluvio-Karstik Depresyonlar (Seydişehir'in Güneybatısından Örnekler). Türkiye Coğrafyası Araştırma ve Uygulama Merkezi Dergisi 5, 229-246.

Doğanay, S., Alım, M., \& Altaş, T. (2006). Atmosfer kökenli doğal afetlere bir örnek: 10 Ağustos 2005 Erzurum seli. Doğu Coğrafya Dergisi, (16), 305-322.

Erinç, S. (1971). Jeomorfoloji II, Genişletilmiş 2. bask1,İstanbul Üniversitesi Yayınları No: 1628, İstanbul Üniversitesi Yayınları No: 23, İstanbul.

Esri. (2020). Band Combinations for Landsat 8. Esri: https://www.esri. com/arcgis-blog/products/product/imagery/band-combinations-forlandsat-8/ (Son Erișim 02.05.2020) adresinden alındı

Flocas, H., Simmonds, I., Kouroutzoglou, J., Keay, K., Hatzaki, M., Bricolas, V., \& Asimakopoulos, D. (2010). On cyclonic tracks over the eastern mediterranean. Journal of Climate, 23(19), 5243-5257.

Ford, D. C. \& Williams, P. W. (1989). Karst geomorphology and hydrology (Vol. 601). London: Unwin Hyman.

Ford, D. C. \& Williams, P. W. (2007). Karst Hydrogeology and Geomorphology. Wiley, Chichester, 562.

Fural, Ş., \& Cürebal, İ. (2019). Elmalı'da (Antalya) Yağışın tetiklediği sel, taşkın ve çamur akıntısı afetlerinin jeomorfolojik analizi. Jeomorfolojik araştırmalar Dergisi, (3), 49-61.

Gams, I. (1978). The polje: the problem of definition. Zeitschrift fuer Geomorphologie, N F 22-2, 170-181.

Gams, I. (2005). Tectonics impact on poljes and minor basins (Case studies of Dinaric Karst). Acta Carsologica, 34(1), 25-41.
Güneysu, A. C., Ozaner, S., \& Erkal, T. (1996). Ölüdeniz Lagünü (fethiye) yakın çevresinin jeomorfolojisi ve karst ortamının özellikleri. Türk Coğrafya Deregisi, 31, 305-312.

Hazir, İ., Akgül, M., Alkaya, M., \& Dağdeviren, M. (2016). 27 Ocak 14 Mart 2012 Tarihleri Arasında Hatay İli Amik Ovasında Meydana Gelen Taşkınların Coğrafi Bilgi Sistemleri Kullanılarak Değerlendirilmesi. 4. Ulusal Taşkın Sempozyumu. Rize.

IPCC. (2007). Climate Change 2007: Impacts, Adaptation and Vulnerability. Contribution of Working Group II to the Fourth Assessment Report of the Intergovernmental Panel on Climate Change, 1st Ed. Cambridge and New York: Cambridge University Press.

İzbırak, R. (1977). Sistematik Jeomorfoloji, Ankara: Ankara Üniversitesi DTCF Yayınları.

Jennings, J. N. (1985). Karst Geomorphology. Géographie Physique et Quaternaire, 39(3), 327.

Kopar, İ., Polat, S., Hadımlı, H., \& Özdemir, M. (2005). 4-6 Mart Pulur çayı (Ilıca-Erzurum) sel-taşkın afeti. Doğu Coğfrafya Dergisi, (13), $187-218$

Lu, D., \& Weng, Q. (2007). A survey of image classification methods and techniques for improving classification performance. International Journal of Remote Sensing, 28(5), 823-870.

McFeeters, S. K. (1996). The use of the Normalized Difference Water Index (NDWI) in the delineation of open water features. Int. $J$. Remote Sens., 17, 1425-1432.

Nazik, L. (2004). The karst regions of Turkey (According to the Morphogenesis and Morphometric Properties). Proceeding of Int Symp. on Earth System Sciences, 77-82, Istanbul-Turkey.

Özdemir, H. (2006). Havran Çayı'nın (Balıkesir) Taşkın sıklık analizinde gumbel ve log pearson tip III dağılımlarının karşılaştırılması. Coğrafi Bilimler Dergisi, 6(1), 41-52.

Özdemir, H. (2007). Farklı Senaryolara göre taşkın risk analizi: Havran çayı örneği (Balıkesir). TMMOB Afet Sempozyumu Bildiriler Kitabı, (s. 155-167). Ankara.

Özdemir, H., \& Bayrakdar, C. (2007). 16 Kasım Tuzla Deresi taşkının nedenleri üzerine bir araştırma. Türk Coğrafya Dergisi, 123-140.

Özdemir, H. (2011). Havza morfometrisi ve taşkınlar, Fiziki coğrafya araştırmaları: Sistematik ve bölgesel. D. Ekinci (Ed.), Havza morfometrisi ve taşkınlar içinde (s. 507-526). İstanbul: Türk Coğrafya Kurumu Yayınları.

Özdemir, H., \& Elbaş1, E. (2015). Benchmarking land use change impacts on direct runoff in ungauged urban watersheds. Physics and Chemistry of the Earth, Parts A/B/C, 79-82, 100-107.

Şahin, K. (2002). Çarşamba ovası ve yakın çevresinde sel afeti (27 Mayıs 2000). Türk Coğrafya Dergisi, (39), 79-95.

Şenel, M. (1997). Türkiye jeoloji haritaları Fethiye L 8 Paftası. Ankara: MTA.

Şimşek, M., Doğan, U., Öztürk, M. (2020). Polyelerin Sınıflandırılması ve Toroslardan Örnekler. Jeomorfolojik Araştırmalar Dergisi, 5, 1-14.

Trenberth, K. E., Dai, A., Rasmussen, R. M., \& Parsons, D. B. (2003). The Changing Character of Precipitation. Bulletin of the American Meteorological Society, 84(9), 1205-1218. 
Turoğlu, H., \& Özdemir, H. (2005). Bartın'da Sel ve Taşkınlar: Sebepler, etkiler, önleme ve zarar azaltma önerileri. İstanbul: Çantay Kitabevi.

Turoğlu, H. (2011). Flashfloods and Floods in Istanbul. Ankara Üniversitesi Çevrebilimleri Dergisi, 3(1), 39-46.

Uşkay, S., \& Aksu, S. (2002). Ülkemizde taşkınlar, nedenleri, zararları ve alınması gereken önlemler. (421). İMO.

Uzun, A. (1995). Erzurum çevresindeki sellere bir örnek: 16 Ağustos 1994. OMÜ Ĕ̈itim Fakültesi Dergisi, (9), 246-260.

$\mathrm{Xu}, \mathrm{H}$. (2006). Modification of normalised difference water index (NDWI) to enhance open water features in remotely sensed imagery. Int. J. Remote Sens., 27, 3025-3033.

Wetherald, R. T., Manabe, S. (2002). Simulation of hydrologic changes associated with global warming. Journal of Geophysical Research, 107(D19).

Yalçınlar, İ. (1995). Altmışbir kişiyi öldüren İzmir sel afeti. Türk Coğrafya Dergisi, (30), 1-6.
Y1lmaz, E. ve Çiçek, İ. (2016). Thornthwaite climate classification of

Turkey<p\&gt;Türkiye Thornthwaite iklim sınıflandırması, Journal of Human Sciences, 13(3), 3973-3994.

Zeybek, H. (1998). 22 Mayıs 1998 havza sel-taşkın felaketi. Ondokuz Mayıs Üniv. Ĕgitim Fakülte Dergisi, (11), 157-164.

www.haberturk.com/tr (Erişim: 31.01.2019)

https://www.ntv.com.tr/ (Erişim: 31.01.2019).

https://gercekfethiye.com/ (Erişim: 31.01.2019).

https://www.kulturportali.gov.tr/turkiye/mugla/ gezilecekyer/kayakoy

https://www.mgm.gov.tr/ (Erişim: 27.08.2020)

https://www.mgm.gov.tr/FILES/iklim/iklim_siniflandirmalari/

Thornthwaite.pdf (Erişim 25.12.2018).

https://www.wetterzentrale.de/reanalysis.php?map, K. C.

https://www.wetterzentrale.de/ reanalysis.php?jaar 